\title{
Financial viability and environmental aspects in the selection of energy sources for sanitary hot water (SHW) and heated swimming pools
}

\section{Viabilidad financiera y aspectos ambientales en la selección de fuentes de energía para agua caliente sanitaria (ACS) y piscinas climatizadas}

\author{
LONGARELA-ARES, Angeles $\dagger^{*}$ \\ Universidade da Coruña, Regulation Research Group, Economy and Finance (GREFIN), Department of Business, Faculty \\ of Economics and Business, Elviña, 15071 La Coruna, Spain.
}

ID $1^{\text {st }}$ Author: Angeles, Longarela-Ares / ORC ID: 0000-0003-0488-4950

DOI: $10.35429 /$ EJM.2019.23.10.46.70

Received July 31, 2019; Accepted September 30, 2019

\begin{abstract}
Sustainability and energy efficiency are topics of great interest, especially in the sports facilities management sector, due to the high energy costs. One of the most relevant costs is derived from the consumption of Sanitary Hot Water (SHW) and swimming pool. The objective of this work is to study new ways to manage and reduce these costs through the valuation of the use of traditional and renewable energy sources and the necessary investment to contribute to the promotion of a more sustainable vision of business management. Four alternative energy installations (Natural Gas, Biomass, Solar Thermal Combined with Natural Gas or Biomass) are proposed, it is verified which is more suitable in terms of financial viability and one of them is selected. For this purpose, we start from a hypothetical businesscase and a 20-year forecast of the energy consumption, the costs and initial investment of each alternative is made; viability analysis are performed with the Net Present Value (NPV) and the obtained results are compared. The conclusion is that the most appropriate solution, from a financial point of view, for sports centers similar to the business-case and with the considered circumstances, is the installation of Biomass, an option that, in addition, can be considered respectful with the environment.
\end{abstract}

Sanitary Hot Water, Renewable Energies, Sports Facilities, Financial Evaluation, Business Sustainability

\begin{abstract}
Resumen
La sostenibilidad y la eficiencia energética son temas de gran interés, especialmente en el sector de gestión de instalaciones deportivas, debido a que presentan elevados costes energéticos. Uno de los costes más relevantes es el derivado del consumo de Agua Caliente Sanitaria (ACS) $\mathrm{y}$ piscina. Este trabajo tiene como objetivo estudiar nuevas formas para gestionar y reducir estos costes a través de la valoración del uso de fuentes de energía tradicionales y renovables y de la inversión necesaria para contribuir al fomento de una visión más sostenible de la gestión empresarial. Se proponen cuatro alternativas de instalación energética (Gas Natural, Biomasa, Solar Térmica combinada con Gas Natural o con Biomasa), se comprueba cual es más adecuada en términos de viabilidad financiera y se selecciona una de ellas. Para ello se parte de una hipotética empresa-caso y se hace una previsión a 20 años de los consumos energéticos y de los costes y desembolso inicial para cada alternativa; se realizan análisis de viabilidad con el Valor Actual Neto (VAN) y se comparan los resultados. Se concluye que la solución más adecuada, desde un punto de vista financiero, para centros deportivos similares a la empresa-caso y con las circunstancias consideradas, es la instalación de Biomasa, una opción que, además, puede ser considerada respetuosa con el medio ambiente.
\end{abstract}

Agua Caliente Sanitaria, Energías Renovables, Instalaciones Deportivas, Evaluación Financiera, Sostenibilidad Empresarial

Citation: LONGARELA-ARES, Angeles. Financial viability and environmental aspects in the selection of energy sources for sanitary hot water (SHW) and heated swimming pools. ECORFAN Journal-Mexico. 2019, 10-23: 46-71.

\footnotetext{
* Correspondence to Author (email: angeles.maria.longarela.ares@udc.es)

$\dagger$ Researcher contributing first author.
} 


\section{Introduction}

In recent years, energy prices have been subject to a gradual increase that has caused companies to consume energy from a marginal item in Their cost structure to a considerable part (ATECYR, 2011). This has led them to Rethink Their management, without losing the advantages it grants (higher productivity and quality) Because business Efforts Have Been traditionally based on the overall efficiency of Processes neglecting consumption, something the current economic Necessary Given situation.

In sports facilities, energy consumption is one of the Most Important items of the company's expenses, Representing the Sanitary Hot Water (SHW) and the heating of the pool water (Pool), 25\% of the total energy consumption (Ministry of Economics and Technological Innovation, 2005). This makes its management look demeanor if it is not accompanied by appropriate thermal conditions in showers and heated pools (Municipal Sports Foundation, 2011). The choice of a suitable energy installation can allow the company to reduce its consumption, making it more competitive in costs, improving its efficiency and contributing to a business model that is respectful of the environment and more sustainable, Which will have a better brand image and will grant a competitive and differentiating advantage.

These questions make interesting the study of the selection of a SHW installation and pool water heating, and therefore it was chosen as the subject of this work.

What is intended is to make a comparison of four alternatives of ACS and pool facilities: a conventional installation of Natural Gas (non-renewable energy), a Biomass installation (renewable energy based on the consumption of organic fuel, such as pellets) and two Solar Thermal installations (combined with each of the first alternatives, giving rise to two hybrid installations). The objective is to select the most appropriate for a sports center considering the financial evaluation of the various alternatives and commenting on the impacts and environmental aspects of each of them.
The work is structured as Follows: section 2 presents the state of the art and description of the business-case; Section 3 shows the methodology; Section 4 sets out the results; Section 5 comments on the conclusions; Section 6 collects the bibliography used and Appendix 1 collects some of the tables With the data and calculations made, which for reasons of space, and to facilitate reading, could not be incorporated into the text

\section{State of the art and description of the company-case}

\subsection{State of the art}

Sports facilities are characterized by special energy needs different from those of any other type of business. This peculiarity is due to its high loads of heat and electricity consumed (Artuso \& Santiangeli, 2008) since they are usually used by a large number of people who consume resources, mainly water and energy.

Applying measures that, in addition to reducing consumption, reduce the environmental impact, such as the installation of SHW systems and heating of pool water with clean energy, will mean responsible action that, if it is also feasible and economically viable, can be applied to other types of environments or sports centers. In Addition, the construction and rehabilitation of These sports facilities is a good opportunity for the introduction of environmental criteria, especially in terms of energy efficiency, with the impact That These types of Measures Have on the economic expenses of the facilities operation (Fraguas Herrero, 2010).

It becomes interesting to value the installation of innovative equipment, with high energy efficiency; maintain these equipment regularly and change them depending on the performance evolution and provide energy supply systems such as active or passive solar energy, wind engines, heat pumps, etc. (Fraguas Herrero, 2010). Likewise, regulations Have Been established, Such as document HE4 of the Technical Building Code (CTE), Which Encourage the use of clean energy in new buildings, When the main source of energy is not renewable (Natural Gas), of such that there must be a minimum solar contribution to SHW and pool water heating. 
Some of these projects to be evaluated by companies, and which represent an important decision that will have an impact on their future costs, are investment projects in energy facilities. Probably, The most used decision rule to choose The most efficient alternative Among the different projects, to ASSESS and analyze the viability from a financial point of view is the net present value (NPV) or the present value of the benefits less the present value of the costs used by economists to defend the adoption of Energy Efficiency Measures by Individuals and Organizations (Galan Gonzalez Leal \& Varela, 1999; Dhavale \& Sarkis, 2015).

Nikolaidis, Chatzis \& Poullikkas (2018) performed a life cycle cost analysis, a NPV analysis and an uncertainty analysis to assess the impact of intermittent renewable energy sources. In order to obtain the components of the NPV, they considered that the general expenses of an electrical energy storage facility include the investment costs or initial cost of the project or installation, the operation and maintenance costs.

Chakrabarty and Islam (2011) and Palit, Malhotra and Kumar (2011) also consider similar VPN components as those of Nikolaidis, Chatzis \& Poullikkas (2018), although Chakrabarty and Islam (2011) complement their study with an eco-efficiency analysis and Palit, Malhotra and Kumar (2011) approach it from the perspective that if the present value of the cost (CPV) of an energy project based on biomass gasifiers (BGPP) is less than or at least equal to the present value of the benefits accrued by the Project Implementation Agency (PIA) of the electricity sale (BPV) throughout the life of the project, this will be financially viable.

There are several studies in esta area. Some authors focus on a specific type of energy that usually includes some energy considered renewable and analyze the viability of Said project. This is the case of authors: such as Brittany (2007), Which Focuses on the financial valuation of a biomass installation, Condori Yucra (2010) and Corral (2011) That focus on solar installation, or Noguera (2011) That Focuses in analyzing a project, which combines several types of energy: solar thermal, geothermal and biomass.
On the other hand, other authors choose to compare several alternatives that allow selecting among different types of energy the most appropriate for a given case. This is what Martínez Sánchez (2011) and Moreno (2012), which focus, respectively, on comparing a microgeneration system of thermal energy and electricity with conventional systems and a diesel installation with a biomass installation to consider replace it. O Chakrabarty \& Islam (2011) who Carried out a financial feasibility analysis of domestic Solar Systems with six case studies, comparing previous expenditures on conventional energy sources before implementing the system.

In any case, the procedure is similar defining in the first place the Characteristics of the building or place Where the installation to be EVALUATED is going to be Implemented, making calculations of a technical nature and, subsequently, of a financial nature, Such as the NPV, to ASSESS the installation, and exposing the Appropriate conclusions in view of the results.

There are both real case studies (Chakrabarty \& Islam, 2011; Corral, 2011), Where the feasibility analysis will be used to determine Whether to Maintain or change the Existing facility, Such as business-case studies Arising from academic projects, business projects not Carried out yet or studies that are based on real data of buildings, swimming pools or sports centers that can serve as a base (Noguera, 2011), Where analyzing the feasibility will be used to choose what type of installation to perform. Some studies focus on urban buildings (Martínez Sánchez, 2011; Moreno, 2012), homes (Chakrabarty \& Islam, 2011) transferable to the sports field and others in sports centers or swimming pools (Cloquell, Artacho and Santamarina, 2009; Condori Yucra, 2010; Corral, 2011; Noguera, 2011).

Regarding environmental aspects, projects related to energy facilities can generate costs borne by Also society, called external costs, external effects or externalities (Delacámara, 2008; European Investment Bank, 2013). These externalities can influence When selecting a type of SHW installation or another. In the case study, for example, using the solar energy or a renewable energy source will reduce negative flows by reducing consumption and Avoiding costs. 
However, a financial analysis does not include the external effects Usually That the presence of the resource Generates on economic agents other than ITS owner and / or user, That is, on society (Delacámara, 2008). With This in mind, not only financial but environmental issues Also would come into play.

To make more complete decisions, externalities should be duly quantified and taken into account in the analyzes, counting them as costs of the decision if their impact is negative or as benefits thereof, if it is positive. It could be considered, for example, that externalities in facilities that use renewable energy sources above the mandatory percentage would have a positive impact as the reduction of pollution is greater, or that the reduction in fuel consumption or the use of the solar energy sources, would lead to avoided costs in the generation of energy, while Maintaining The Possibility of fully covering the demand (Delacámara, 2008).

The European Investment Bank (2013) to Evaluate the costs and benefits for society, it considers That is Necessary to take into account externalities and Such, For This, They must be added Together with the operation and maintenance costs. This requires an estimate of the volume of externality (for example, tons of greenhouse gas Emissions per year) and an Appropriate unit price, or a marginal estimate of external cost. Although it may be difficult to estimate, the European Investment Bank (2013) has made valuations in euros of some externalities in the sectors in which it operates and considers them a negative flow when calculating the NPV.

Infrastructure Sustainability Council of Australia (ISCA) (2016) starts from the fact That the cost-benefit analysis (CBA) is a financial analysis process to calculate the net costs and benefits of the options Expressed in monetary units and That the results can be express, Among other forms, with the net present value (NPV). From there, the complete economic analysis (CEA) is a tool That Allows expanding the CBA by Including externalities in the evaluation and calculating the net benefits (benefits minus costs) of the options Expressed in monetary units.
However, in the private sector the costbenefit analysis and the NPV do not Usually include externalities When Evaluating some investment projects, in part, due to the lack of Relevant data and the limited time, but Also due to the little emphasis on the external effects (Karmokolias, 1996). This Makes Incorporating externalities into the financial feasibility analyzes can be complicated by the difficulty to be valued monetarily, in some cases being Considered as intangible effects (Delacámara, 2008); other environmental effects do not lend themselves easily to quantification due to their nature (Karmokolias, 1996) and, although significant progress has been made in refining the estimates of values and methods to integrate them into the analysis, it is still necessary to expand the range of externalities considered, not only harmful emissions, but also others such as loss of biodiversity and ecosystem services (European Investment Bank, 2013).

Taking into account the considerations mentioned, this work will focus on the financial evaluation of various alternatives for an ACS installation and heated pool, without considering externalities and environmental costs at the empirical level. However, the environmental aspects and impacts of each alternative will be Discussed by Describing the level of pollution and $\mathrm{CO} 2$ Emissions of the different alternatives based on the investment decision in traditional or renewable energy projects.

\subsection{Business-case description}

In the present study, a hypothetical businesscase is used, which have the following characteristics: construction of 3,984 m2 (not counting the fuel silo, if applicable) located in lugo. It consists of several units, on two floors, and special attention will be given to those involved in the management of shw and pool water, listed in table 1 below: 


\begin{tabular}{|c|c|c|c|c|}
\hline & $\begin{array}{c}\text { Sheet of } \\
\text { water }\end{array}$ & Height & $\begin{array}{c}\text { Pool } \\
\text { volume }\end{array}$ & $\begin{array}{c}\text { Glass } \\
\text { surface } \\
\text { (walls and } \\
\text { floor) } \\
\end{array}$ \\
\hline $\begin{array}{l}\text { Indoor } \\
\text { pool or } \\
\text { Pool } 1\end{array}$ & $\begin{array}{l}312.5 \\
\mathrm{~m} 2\end{array}$ & $\begin{array}{l}1.5 \mathrm{~m} \\
\text { high at the } \\
\text { front } \\
2.5 \mathrm{~m} \\
\text { high at the } \\
\text { rear } \\
\text { Average } \\
\text { height of } \\
2 \mathrm{~m}\end{array}$ & $625 \mathrm{~m} 3$ & $462,50 \mathrm{~m} 2$ \\
\hline $\begin{array}{c}\text { Splash } \\
\text { Pool } \\
\text { Indoor - } \\
\text { Pool } 2\end{array}$ & $70 \mathrm{~m} 2$ & $\begin{array}{l}1.2 \mathrm{~m} \\
\text { average } \\
\text { height }\end{array}$ & $84 \mathrm{~m} 3$ & $104 \mathrm{~m} 2$ \\
\hline $\begin{array}{l}\text { Changing } \\
\text { rooms }\end{array}$ & $\begin{array}{l}318 \mathrm{~m} 2 \\
\text { toilets an } \\
\text { With toil }\end{array}$ & $\begin{array}{l}\text { users and } \\
\text { inks) and } \\
\text { and sinks). }\end{array}$ & $\begin{array}{l}\text { onitors } \\
\text { iliary se }\end{array}$ & $\begin{array}{l}\text { ith showers } \\
\text { vices }(12 \mathrm{~m} 2\end{array}$ \\
\hline
\end{tabular}

Table 1 Dependencies involved in the management of hot water and pool water Source: Self made

Company profile-event is geared to be a market leader. The sports center begins to be built in year 0 , opens its doors at 21 months of beginning to be built, that is, on October 1 of year 1 and Year 2 it is the first full year of operation and considered as the base year. The monthly inflow for a total of 12,476 uses / month, according to forecasts for year 2, based on guidance from professionals. It is based on the characteristics of a sports center with a wide range of courses and supervised activities, taught at various times to a maximum of people per session, and free activities (swimming pool, fitness, paddle, tennis ...).

Uses are considered not sales, because, for example, a person enrolled in a course of 2 days per week is considered as a single sale, but as 8 uses per month. For courses and supervised activities, applications were set at $40 \%$ of the maximum number of people per session that could come to be, because in the first years of operation it is usually the common influx and for free activities are directly estimated the number was directly estimated of monthly uses, in accordance with the guidelines of sports center managers (table 2.1 APPENDIX 1). In the case of number of subscribers (sales, no use) is expected up to 5,000 customers as a stop, growing from 2,000 subscribers $(40 \%$ of 5,000 ) is in year $250 \%$ for year $3,33 \%$ for 4 , $15 \%$ for 5 and $5 \%$ to 6 reaching 4,817 subscribers.

\section{Methodology}

The methodology for performing this study is divided into three phases:

- $\quad$ Calculate power in kilowatts $(\mathrm{kW})$ that is required to have the facility for hot water and pool water heating and annual energy consumption in kilowatt hours (kWh).

- Investment, initial or installation costs and operation and maintenance costs of each type of installation.

NPV calculation of each type of installation.

In addition, relevant environmental aspects of the alternatives considered, such as the estimated $\mathrm{CO} 2$ emissions for each type of SHW installation and heated pool valued at work, will be discussed.

Since the study focuses primarily on a financial level, not on an assessment of environmental costs or impact of emissions, were considered only economic variables such as prices and investment costs or initial and installation costs, operating costs and maintenance costs of each type of installation in the financial analysis and were complemented with appropriate justifications according to which some alternatives are considered more sustainable than others, based on their $\mathrm{CO} 2$ emissions and environmental aspects.

To determine the power and energy consumption, the formulas of power and energy contained in Albarracín, Sanabria and Maíllo (2007), the "Technical Guide Hot Water Central" ATECYR (2011) and expert technical advice were used. Likewise, information on similar academic works was obtained and the procedure used in these, or any of its steps, was followed for the different sections (Britain, 2007; Cloquell, Artacho and Santamarina, 2009; Condori Yucra, 2010, Corral, 2011; Noguera, 2011; Martínez Sánchez, 2011; Moreno (2012), Also, it was used an energy efficiency manual by Escobar (2009) and an audit by Creara (2011), studies that also served as guidance for financial analysis, in addition to Chakrabarty and Islam (2011), Palit, Malhotra and Kumar (2011) and Nikolaidis, Chatzis and Poullikkas (2018), to determine the components of the NPV. 
All calculations were made based on year 2, as it is the first full year of operation of the sports center, except for the NPV calculation for which a 20-year forecast is applied. Although in the future the number of clients increases, energy facilities should be based on the most conservative and the early data, as if estimates are met they can always be increased. Data used were obtained from various sources are discussed in detail below, together with the methodology used in each phase.

Traditionally assessing the viability of projects has been carried out based on financial aspects. However, at present, it is important to assess how well a project is able not only to generate profit or be viable, but also to reduce negative impacts on the environment, and see how they can take into account the issues and environmental costs.

To determine the environmental impacts and $\mathrm{CO} 2$ emissions data were applied and indications and formulations of the Practical Guide for calculating emissions of greenhouse gases (ghgs) by the Generalitat de Catalunya (2011) and IDAE (2019) were followed in the stage of energy consumption, as well as the method to value economically $\mathrm{CO} 2$ emissions from European Investment Bank (2013).

\subsection{Methodology for calculating power and energy consumption}

To determine the thermal power and energy consumption, on the one hand, it was calculated the consumption of liters of SHW and thermal energy demand which will involve the locker room and on the other hand, the power and energy demand of swimming pools, since in each case will be obtained differently. The power for hot water, hot water consumed for health services (showers and toilets, mainly) was calculated from daily water consumption, which is given by the daily influx of people to the center and liters each person consumes. The daily influx is determined from the monthly influx. Since it varies every month, especially in summer, due to the seasonality of use of sports centers, guidance influx rates were established, taking 12. 476 uses as the months in which the monthly inflow level is $100 \%$ of the expected (Table 2.2 Appendix 1).
Subsequently, the monthly uses were added to know the annual ones and, from these, the average monthly and daily uses (345 people/day) were obtained.

In respect of pools, they consume hot water due to 2 main causes: constitute the first time the pool glass is filled and the heat losses of the glass due to five factors: evaporation, radiation, convection, transmission and water renewal. This will mean having to use hot water to maintain the temperature at the appropriate levels (between $24^{\circ} \mathrm{c}$ and $30^{\circ} \mathrm{c}$, according to the RITE Wellness and Health Requirement IT 1.1). A temperature of $28^{\circ} \mathrm{c}$ was chosen for pool 1 and $30^{\circ} \mathrm{c}$ for 2 , because according to the RITE and orientations of real sports centers, pool 2 if used by babies, senior citizens and pregnant women, should have a higher temperature.

Energy consumption will be given in kilowatt hours (kwh). On the one hand, we have the energy consumption of SHW and, on the other hand, those of swimming pools. The annual energy consumption (kwh) shall be calculated by the product of the installed power (kw) for the hours that power is expected to be used annually.

\subsection{Methodology for calculating investment costs or initial installation, energy costs and maintenance costs}

Once the power to be installed was calculated, the installation costs were determined for each alternative (Natural Gas, Biomass and Solar combined with Natural Gas or Biomass), based on estimates of professionals and catalogs of boilers and solar panels such as Vaillant rate catalog or the Herz price generator.

The facilities are adapted to document HE4 of the Technical Building Code (CTE) which, since 2006, establishes that, in new buildings, when the main source of energy is not renewable (Natural Gas), there must be a minimum solar contribution to SHW and pool. In SHW this contribution will depend on the solar zone (Lugo is Zone II) and the hot water consumer (between 5,000 and 10,000 liters / day) that will be $40 \%$ of the energy demanded for SHW. For swimming pool heating it will depend on the solar zone and will be $30 \%$ of the energy demanded for swimming pools. 
To determine the number of solar panels required, the required contribution will be calculated according to the percentages mentioned, the heat exchanger savings will be taken into account and the auropro3.0.1 program of Vaillant will be used to calculate the number of solar panels needed for SHW and pool.

In addition, it will be taken into account in the cost of facilities the subsidies for renewable energy projects of INEGA 2018, which for the Biomass boiler is $€ 360 / \mathrm{kw}$ of installed power, with a $50 \%$ maximum aid percentage, and for Solar Thermal energy installations, for the non-mandatory part of the CTE and being combined with conventional energies, of $€ 1500 / \mathrm{kw}$ with a $50 \%$ maximum aid percentage.

From the energy consumption data with fuel prices biomass set by the IDAE (Institute for Saving and Energy Diversification), prices of Natural Gas Endesa (2018) for consumptions between 100,000 kwh / year and $3 \mathrm{gwh} /$ year with Rate 3.4. Recommended by Endesa professionals and document HE4 Building Technical Code for solar panels, the annual energy cost of each type of installation is determined.

To determine the energy cost of "Natural Gas" annual energy consumption savings exchanger was used, minus the mandatory minimum solar contribution, since this contribution is free. When installing a condensing boiler must be noted that the yield is $104 \%$, so that with each $\mathrm{kwh}$ produced will be covered $1.04 \mathrm{kwh}$ and therefore consumption will be covered with less energy production (Production $=$ Consumption $/$ Performance $)$. The production result obtained was multiplied by the price of the most economical Natural Gas in the market for consumption between $100,000 \mathrm{kwh} /$ year and $3 \mathrm{gwh} /$ year with the rate 3.4. (Endesa, 2018), taking into account the monthly fixed term.

For the cost of consumption of "biomass", the price of wood pellets in bulk (one of the fuels of this type of boiler) in $€ /$ kwh with an average price of the A1 certified pellet in bulk is $€ 0.0366 / \mathrm{kwh}$ and uncertified pellet bulk $€ 0.0352 / \mathrm{kwh}$, according to the IDAE liberalized energy prices report (20172018) and professionals in the sector.
The average of both is $0.0359 € / \mathrm{kwh}$. It was multiplied by the production of energy needed to cover annual energy consumption with savings of discounted exchanger (production will be greater than consumption, since it has a Biomass boiler with a yield of 93\% that covers $0.93 \mathrm{kwh}$ for each $\mathrm{kwh}$ produced).

For installations with voluntary solar contribution, the corresponding solar contribution was subtracted from the annual energy consumption with exchanger savings. In the case of the "Solar combined with Natural Gas" installation, the energy costs were determined as indicated for installation "Natural Gas", and for "Solar Biomass" installation, as in the case of installation "Biomass ".

And, based on estimates of professionals in the sector, maintenance costs were calculated. There are common maintenance costs for any of the alternatives analyzed. On the one hand, there are the mechanical maintenance costs related to monthly preventive operations of checking the energy equipment (12h / month), of daily operations of temperature control of the deposits and pool $(2 \mathrm{~h}$ / day), and of corrective operations for assistance or unforeseen events (200h per year) and, on the other hand, chemical maintenance costs, performed by an approved laboratory, such as legionella and PH analysis of SHW and swimming pool $(€ 6,000)$. The first ones will be given by the cost / hour of the necessary personnel and by the hours that are in the center and the second ones have a fixed price. Moreover, in the biomass installation there will have to be a person in charge of removing the ashes from the fuel weekly (52 hours per year) and a monitoring plan will be carried out in the thermal solar installation (cleaning of panels and control of collectors and circuits) and maintenance of the collection, accumulation and exchange systems, hydraulic circuit and electrical system.

\subsection{Methodology for feasibility analysis (NPV)}

Depending on the results, it made a comparison of the alternatives, paying particular attention to costs and initial investment, and financial viability of each option was studied using an NPV analysis. 
For the calculation of the NPV, a time horizon equal to the useful life of the facilities was established, 20 years, setting as down payment the cost of the installation (with subsidy) and as cash flows the annual energy costs added to the costs of maintenance. Being disbursement flows will be negative and therefore the result of NPV too, so that one with a higher NPV will be proposed as a more adequate installation, despite being all negative.

To make temporary projections of 20 years the increase in the influx of people to SHW was taken into account. In year 1 the flow is the fourth part of year 2, the center being open for only a quarter. Since the flow 2 increases by $50 \%, 33 \%, 15 \%$ and $5 \%$ in years $3,4,5$ and 6, respectively, with the same ACS consumption being maintained since it will vary in these proportions. The pool will consume the same every year, except for losses the first year, to work only during the opening three months since October, will be the fourth of the year 2 . The first cup filling is made in October and the following filled year in December. Other years are filled alternately. After the first filling of swimming pools in October of the opening year 1 , and of the filling of the year 2 calculation base, the entire pools will be emptied only when repairs are required, and only a part is usually emptied for minor repairs. As the company of this study is a quality benchmark and to anticipate possible repairs, it was considered a commissioning every two years.

The NPV formula is shown in table 9 of Appendix 1. The effect of inflation has not been considered, since when applying a rate $g$ multiplying the price of each year $n$ by $(1+$ $\mathrm{g})^{\wedge} \mathrm{n}$, in the formula of the NPV the discount factor $(1+g)^{\wedge}-n$ must be added, and the same result would be obtained as without an inflation rate (Garrido, 2001). The WACC (Weighted Average Cost of Capital) is considered a discount rate, based on an estimate of the total cost of building a sports center with the characteristics of the business-case and and from the costs of debt according to orientations of experts of the sector of management of sports facilities and advisers of banking entities. Upgrading to a discount rate of $8.40 \%$ WACC offers the same conclusions as to consider inflation at $3 \%$ and upgrade to a rate of $11,65 \%$ (taking into account the effect of inflation, $(1+$ $0.084) *(1+0.03))$.
This WACC value is appropriate, used in studies of similar nature in which for an energy project to be carried out in the company can be used as the discount rate WACC of this (Noguera, 2011).

\subsection{Methodology for calculatingenvironmental impacts and CO2 emissions}

The analysis of external costs and environmental externalities means greater transparency in the management, more information about the activities to be analyzed and less discretion of some decisions. The literature on the economic valuation of environmental external costs, agrees on the need to match two unequal but consistent methodological approaches: the approach path impact and life cycle analysis (LCA) and although sometimes not easy to estimate externalities by technical ignorance or lack of means, in any case, it is good to reflect on them (Linares Llamas, 2002. European Investment Bank, 2013; Infrastructure Sustainability Council of Australia (ISCA), 2016).

For energy the life cycle analysis (LCA) comprises the extraction of fuel, transport, preparation, construction, operation and decommissioning of generation, energy transmission and management of waste produced. All these steps have environmental consequences, higher or lower depending on the type of energy.

In the case of natural gas, emissions from extraction, transport and generation, occupation of land, noise and pollutant discharges are generated. In the case of biomass it produces emissions in the cultivation, collection, transportation and generation, waste, residues and occupation of terrain and in the case of solar energy it generates solid waste such as heavy metals in its generation and land occupation and visual impact, however, it does not generate $\mathrm{CO} 2$ emissions (Linares Llamas, 2002).

In addition, for economic evaluation of externalities, there are various applicable methods to quantify in monetary terms damage, such as the "top-down" method Hohmeyer (1988), using aggregate data emission and impacts to estimate external costs of certain contaminants. 
Approach "bottom-up" using specific values for each unit of production or energy demand (Bernow \& Marron, 1990; Ottinger et al., 1991; Pearce et al., 1992); damage function, a succession of steps following the impact from the activity that generates it until the damage that occurs independently for each activity and impact considered; a methodology applied by the European Commission $(1995,1999)$ for the externe project ( Linares Llamas, 2002) or as the European Investment Bank (2013) that estimates the volume of an externality and an appropriate unit price, or a marginal estimate of external cost.

In the consumption stage, which this study focuses on, natural gas is a fuel that contributes to increasing $\mathrm{CO} 2$ emissions. The Practical Guide for the calculation of greenhouse gas (GHG) emissions (Generalitat de Catalunya, 2011) involves the emission of $2.15 \mathrm{~kg} \mathrm{CO} 2$ / Nm3 of natural gas.

Biomass is a fuel with emissions considered practically neutral (Generalitat de Catalunya, 2011), a zero-emission factor will be applied (t CO2 / TJ Nm3).

Solar energy means less CO2 emissions, covering part of the need to produce energy with other non-renewable sources and is considered to have zero emissions.

In this paper, to analyze the environmental impact, it has chosen to focus on $\mathrm{CO} 2$ emissions at the consumption stage only since when it comes to incorporating the valuation of externalities in an economic or financial analysis there are usually several difficulties. Some difficulties may be of a technical nature, related to the risk of incurring double counting of securities, ie incorporate two or more times the same welfare loss, then overestimating the externality, and can be complementary and competitive features for the same resource (Turner et al., 2003) or problems with the scale data, since in order to analyze economically externalities, it may be used estimations obtained for similar analysis, in other places or circumstances, and that could mean not transferring the results properly to context of the analysis being developed (Delacámara, 2008).
To determine $\mathrm{CO} 2$ emissions at the consumption stage, the following considerations were taken into account:

\section{- Natural gas, according to the Practical Guide for calculating emissions of greenhouse gases (GHGs) (Generalitat de Catalunya, 2011) involves the issuance of $2.15 \mathrm{~kg} \mathrm{CO} 2$ / Nm3 of natural gas. \\ - Biomass is a fuel with emissions considered practically you neutral (Generalitat de Catalunya, 2011), are subject to a zero emission factor ( $\mathrm{t} \mathrm{CO} 2$ / TJ Nm3). \\ - Solar energy means less CO2 emissions, covering part of the need to produce energy with other non-renewable sources.}

In addition, according to the European Investment Bank (2013), CO2 emissions could be economically valued in EUR / t CO2e. The European Investment Bank (2013) makes a central estimate of the damage associated with an emission in 2010 of 25 euros per tonne of carbon dioxide equivalent, plus a high and low estimate of 40 euros and 10, respectively (all measured in constant euros of 2006). Reflecting a common finding that the marginal damages of emissions increases as a function of atmospheric carbon concentrations, annual "adders" are applied after 2010, ie, an absolute increase in value per year (measured in prices constant 2006). Therefore, an issue in 2017, the year of the study, according to the central estimate would be equal to $25+(2017-2010)=$ 32 (Euro 2006). Thus reducing the consumption of natural gas and bet on hybrid systems combining solar energy, beyond legally binding, or betting on biomass installations, you can assume greater sustainability for the business-case and a positive impact on the consumption stage for the environment.

\section{Results}

\subsection{Results of power and energy consumption}

\section{Power}

Table 3 summarizes the powers necessary for hot water and pool and the power to be installed is collected and then explained as calculated. 


\begin{tabular}{|l|l|}
\hline & $\begin{array}{c}\text { Installed power } \\
(\mathbf{k W})\end{array}$ \\
\hline SHW power & 71.05 \\
\hline Power evaporation & 63.22 \\
\hline Power radiation & 6.62 \\
\hline Convection power & 0.00 \\
\hline Power per transmission & 13.91 \\
\hline Renewing water power & 29.53 \\
\hline Commissioning power pool & 196.89 \\
\hline Total & $\mathbf{3 8 1 . 2 3}$ \\
\hline $\begin{array}{l}\text { Power evaporation }+ \text { renewal }+ \\
\text { radiation) }\end{array}$ & -99.37 \\
\hline Total installed & $\mathbf{2 8 1 . 8 5}$ \\
\hline
\end{tabular}

Table 3 Power installed

Source: Self made

First, the thermal power needed for the production of SHW was determined by finding the one hand consumption liters of water and the thermal energy demand which will provide the locker and on the other, demand for pools, since power in $\mathrm{kw}$ is obtained differently.

Knowing, therefore, that a month come to the center 345 people / day and each person consumes 21 liters of water at $60^{\circ} \mathrm{C}$ (according to the document HE4 "Power Saver" CTE) would consumption SHW of 7,245 liters / day. Therefore, 1 SHW tank of 2,500 liters of capacity will be installed and a time of 2 hours will be considered each time the tank is filled, leaving a necessary power to heat the water at $60^{\circ} \mathrm{c}$ of $71.05 \mathrm{kw}$ (Albarracín, Sanabria and Maíllo, 2007; ATECYR, 2011). As in the base year it is forecast consumption of 7,245 liters and the tank is 2,500 liters if the boiler works 6 hours / day for SHW will produce 7,500 liters in total and, therefore, to 7,245 liters will work 5.8 hours / day. In the event that would increase the flow to the center, if the same percentages apply subscriber growth,

As for the pools, the consumed hot water comes from 2 main causes: constitute the first time the pool is filled and the heat losses from the pool vessel. The heat losses of the pool vessels were calculated (Albarracín, Sanabria and Maíllo, 2007; ATECYR, 2011) adding a necessary power of $113.28 \mathrm{kw}$ and, after filling the pool glasses for the first time, the power to cover the set-up to be consumed each time, for repairs, the pools have to be refilled, it adds a power of $196.89 \mathrm{kw}$.
The total power required would be $381.23 \mathrm{kw}$ (table 3), considering the commissioning, the renewal of the water and the losses power due to evaporation or radiation (Albarracín, Sanabria and Maíllo, 2007; ATECYR, 2011). If one takes into account the punctual use of the commissioning power of the pool and, thinking that when it is produced, the renewal power of the water is already covered and there are practically no losses due to evaporation or radiation, a boiler would be installed to covering a power equal to 281.85 $\mathrm{kw}$. The choice is, therefore, a boiler of $300 \mathrm{kw}$.

\section{Energy consumption}

In terms of energy consumption, on the one hand, if we consider that the SHW power is $71.05 \mathrm{kw}$ and 5.8 hours a day working in year 2 (calculation basis) a daily demand of $412 \mathrm{kwh}$ will occur and, as the center will be open 365 days a year, there will be an energy demand of $150,309.12 \mathrm{kwh}$ per year. On the other hand, pools work the following hours:

- $\quad$ Renovation and transmission (24 hours a day, 365 days a year) and radiation (24 hours a day, 362 days a year, 3 days of setting up the pool vessel) are discounted.

- Commissioning: at the end of year 2 a pool filling, as it is the basis of calculation. Year 1 is the initial warming, and the other years, from $2 *$, one will be filled and no.

- Evaporation: only the hours that the center is open (4,888 hours) minus 72 hours of commissioning are considered, because at that time the water will not evaporate, the pools will be covered with a thermal blanket the rest of the hours that the center is not open.

In this way, 907,001.17 $\mathrm{kwh}$ would be consumed in the base year (table 4 and table 4.1 complete Appendix 1). 


\begin{tabular}{|c|c|c|c|}
\hline & $\begin{array}{l}\text { Installed } \\
\text { power } \\
(\mathrm{kW})\end{array}$ & $\begin{array}{c}\text { Total working } \\
\text { hours } \\
\text { /year }\end{array}$ & $\begin{array}{c}\text { Energy } \\
\text { consumption } \\
\text { (kWh) } \\
\text { annually }\end{array}$ \\
\hline $\begin{array}{c}\text { Total } \\
\text { evaporation } \\
\text { power }\end{array}$ & 63.22 & 4816 & $304,486.95$ \\
\hline $\begin{array}{c}\text { Total } \\
\text { radiation } \\
\text { power }\end{array}$ & 6.62 & 8,688 & 57476.09 \\
\hline $\begin{array}{l}\text { Convection } \\
\text { power }\end{array}$ & 0 & & \\
\hline $\begin{array}{c}\text { Total power } \\
\text { per } \\
\text { transmission }\end{array}$ & 13.91 & 8,760 & $121,834.08$ \\
\hline $\begin{array}{c}\text { Total } \\
\text { renovation } \\
\text { Water power }\end{array}$ & 29.53 & 8,760 & $258,718.57$ \\
\hline ACS power & 71.05 & $2,115.54$ & $150,309.12$ \\
\hline $\begin{array}{l}\text { Total system } \\
\text { capacity } \\
\text { made }\end{array}$ & 196.89 & 72 & 14176.36 \\
\hline \multicolumn{3}{|c|}{ Total } & $907,001.17$ \\
\hline \multicolumn{3}{|c|}{ Saving heat exchanger (Table 4.1) } & $136,586.72$ \\
\hline \multicolumn{3}{|c|}{$\begin{array}{c}\text { Total consumed energy with saving } \\
\text { exchanger }\end{array}$} & $770,414.45$ \\
\hline
\end{tabular}

Table 4 Summary of power, operating hours and consumed energy in the base year calculation Source: Self made

To save part of this consumption can be installed heat exchangers that can recover energy from water renewal pools, saving $136,586.72 \mathrm{kwh}$, being

An annual consumption of $770,414.45$ $\mathrm{kwh}$. These consumption will be affected by the performance

Boilers, requiring produce more or less kwh of which will be consumed, depending on whether performance is above or below 100\% (Energy production $=$ Consumption $/$ Boiler Performance).

Based on the data obtained so far, the cost of each type of installation, the cost of consumption of each of them and the cost of maintenance will be sized and estimated, to make the financial assessment.

\subsection{Results of installation or investment costs, energy or operational costs and maintenance costs}

\section{Installation or investment costs}

Investment costs or installation required to implement each alternative were estimated according to the mentioned methodology.
Based on estimates of industry professionals and catalogs of boilers and solar panels such as the Vaillant catalog or the Herz price generator. A summary of the necessary initial investment or installation costs for each type of alternative listed in Table 5 and detailed estimates are shown in table 5.1

\begin{tabular}{|l|l|}
\hline \multicolumn{2}{|c|}{$\begin{array}{c}\text { Natural gas (with contribution Solar Required } \\
\text { according CTE) }\end{array}$} \\
\hline Natural gas & 30971 \\
\hline Solar Biomass & 93896 \\
\hline Total & $\mathbf{1 2 4 8 6 7}$ \\
\hline \multicolumn{2}{|c|}{} \\
\hline Total biomass & 113635 \\
\hline Grant Inega & 56,818 \\
\hline Total Natural gas Solar Voluntary Contribution (plus \\
\hline \multicolumn{2}{|c|}{ Required) } \\
\hline Total Natural Gas & 30971 \\
\hline Total Solar & 180322 \\
\hline Total & $\mathbf{2 1 1 2 9 3}$ \\
\hline Grant Inega & 60,000 \\
\hline Total & $\mathbf{1 5 1 2 9 3}$ \\
\hline \multicolumn{2}{|c|}{ Biomass Solar voluntary contribution (equal to } \\
\hline mandatory GN) \\
\hline Biomass \\
\hline Solar & 110135 \\
\hline Total Solar Biomass & 93896 \\
\hline Grant Inega & $\mathbf{2 0 4 0 3 1}$ \\
\hline Total with Grant Inega & 60,000 \\
\hline & $\mathbf{1 4 4 0 3 1}$ \\
\hline
\end{tabular}

Table 5 Investment cost or initial cost of each type of facility $(€)$

Source: Self made

$40 \%$ of the annual energy demand for Solar Thermal ACS are 60,123.65 kWh and $30 \%$ of the annual energy demand for Solar Thermal Pools:

To determine the number of solar panels needed the minimum contribution required by the specified percentages are calculated which are $227,007.61 \mathrm{kWh}$, but saving heat exchanger are reduced to $90420.89 \mathrm{kWh}$. With the AuroPro3.0.1 program. Vaillant was calculated that 32 panels for hot water and 97 are needed for pools.

Since heat exchangers are installed in the pools, the document can be reduced HE4 considered mandatory solar minimum thereof, from $30 \%$ to $12.37 \%$, and panels 97 to 40 , representing a total of 72 solar, with ACS panels. 
In addition, taken into account in the cost of facilities, subsidies for renewable energy projects of INEGA (Table 6), which for biomass boilers are of $310 € / \mathrm{kW}$ of installed capacity, with $50 \%$ of project cost maximum support $(56,818 €$ maximum) and energy facilities Solar Thermal, for non-mandatory part of the CTE and being combined with conventional energy, $1500 € / \mathrm{kW}$, with $50 \%$ of the project cost and $60,000 €$ for project maximum support $(105,647$ and $102,016 € €$ is $50 \%$ in the case of solar thermal systems with more than the minimum required solar panels and maximum subsidized $€ 60,000$ ).

\begin{tabular}{|l|l|}
\hline \multicolumn{3}{|c|}{ Biomass subsidy/grant } \\
\hline Maximum power assistance & $\begin{array}{l}\text { Maximum support per } \\
\text { project }\end{array}$ \\
\hline $\begin{array}{l}310 € / \mathrm{kW}-(\mathrm{P} / 4) \text { for } \\
\text { additional power } \mathrm{P} \text { of } 40 \mathrm{~kW}<\mathrm{P} \\
\leq 440 \mathrm{~kW} \text { with automatic } \\
\begin{array}{l}\text { feeding and accumulation } \\
\text { volume fuel V } \geq 250 \text { liters and V } \\
<1,000 \text { liters and } 50 € / \mathrm{kW} \text { if } \\
\text { system automatic cleaning } \\
\text { exchanger }\end{array}\end{array} \begin{array}{l}\text { The maximum amount of } \\
\text { aid per project will be } € \\
60,000 .\end{array}$ \\
\hline \multicolumn{3}{|c|}{ Solar Thermal Grant } \\
\hline Maximum power assistance & $\begin{array}{l}\text { Maximum support per } \\
\text { project }\end{array}$ \\
\hline $1500 € / \mathrm{kW}$ & $\begin{array}{l}\text { The aid intensity will be } \\
50 \% \text { The maximum } \\
\text { amount of aid per project } \\
\text { will be } € 60,000 .\end{array}$ \\
\hline
\end{tabular}

Table 6 INEGA subsidies for renewable energy Source: Self made

Installation alternatives contemplated are therefore:

- Natural Gas facility that will comply A Natural Gas facility installation that will comply with the mandatory solar minimum including 71 panels and will not have any subsidy.

- An installation exclusively of Biomass, with a subsidy of $€ 56,818$.

- A solar installation combined with Natural Gas, with solar input higher than the mandatory one $(51 \%$ to SHW and $31 \%$ to swimming pool), 142 panels, 71 volunteers, with a subsidy of $€ 60,000$.

- And a Solar installation combined with Biomass in which the minimum amount required for conventional energy will be taken as a voluntary solar contribution, with a subsidy of $€ 60,000$.
According to the installation costs (table 5 and table 5.1 Appendix 1) without taking into account the subsidies, the installation that requires a smaller investment is the "Biomass" installation ( $€ 113,635)$ followed by "Natural Gas" (€ 124,867), "Solar combined with Biomass" (€ 204,031) and "Solar combined with Natural Gas" (€ 211,293).

If there is no obligation for the CTE to install a minimum of solar panels when conventional energy is used, the "Natural Gas" installation would be the one that would have the lowest investment costs ( $€ 30,971)$, but this option has not been realizable since 2006.

Taking into account subsidies, the "Biomass" installation would continue to have the lowest price $(€ 56,818)$ and the Solar combined with other energies could be interesting, since its cost is reduced by almost a third of the value without subsidy and they are the alternatives with the highest solar input. In principle, if we only based the analysis on the cost of the investment (CAPEX or Capital Expenditure), the most economical installation would be the "Biomass".

However, it should be seen if it compensates for a larger investment depending on whether in the long term it allows reducing the costs of energy consumption and even other operating expenses (OPEX or Operational Expenditure), for example, the annual maintenance of facilities, before settling on one considering only the investment. In this case, they consider disbursements arising from operating expenses.

\section{Energy costs}

To determine energy costs indicated methodology was followed. These costs for the base year calculation, are shown in Table 7 and Table 7.1 of Annex 1 of more detailed and disaggregated form. Accordingly, the facility would consume less "Solar with Natural Gas", with a cost of $€ 22,327.87$ in the base year, very close to the running costs of the "Solar Biomass" installation. 


\begin{tabular}{|l|c|}
\hline & Natural gas \\
\hline Annual Natural Gas Cost & $29,966.30 €$ \\
\hline & Biomass \\
\hline Annual cost Biomass & $29,739.65 €$ \\
\hline \multicolumn{2}{|c|}{ Solar combined } \\
\hline & $\begin{array}{c}\text { Solar with Natural } \\
\text { Gas }\end{array}$ \\
\hline $\begin{array}{l}\text { Annual cost Solar + Natural Gas } \\
(€)\end{array}$ & \begin{tabular}{c}
$22,327.87 €$ \\
\hline
\end{tabular} \\
\hline Solar + Biomass annual cost $(€)$ & $23,854.95 €$ \\
\hline
\end{tabular}

Table 7 Energy costs of each type of facility Source: Self made

This is due to the fact that the solar contribution is high, exceeding the mandatory minimum, and that the Natural Gas condensing boilers have a higher yield than those of Biomass. The installation with the highest consumption costs is "Natural Gas" (€ 29,966.30) because the mandatory solar contribution does not mean considerable savings, followed by the installation of biomass ( $€$ 29,739.65), which despite being the most energy must produce has a cheaper fuel than natural gas, so it might be interesting, knowing that over the years the influx of people will increase and, therefore, the energy to be produced. Therefore, although in terms of installation costs, "Biomass" would be the option with the lowest investment, at the level of consumption costs, for this company, the most appropriate would be the "Solar with Natural Gas" installation, if its high installation costs are amortized (figure 1). This will be seen in the NPV analysis.

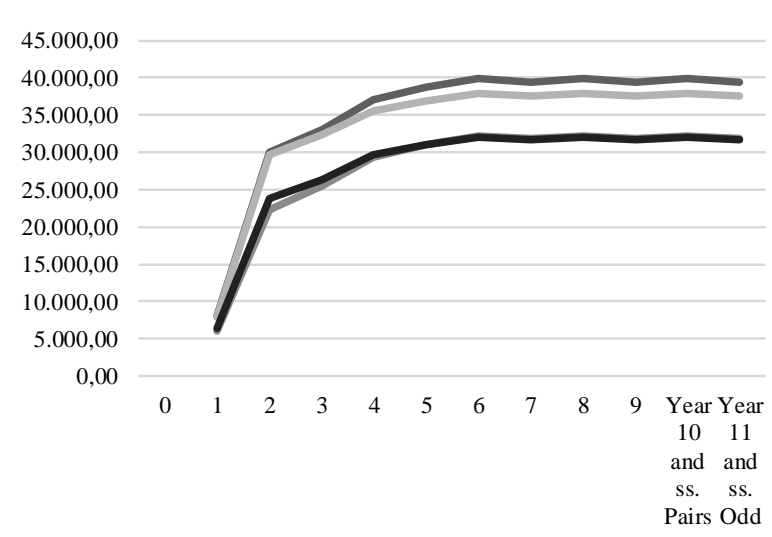

Graphic 1 Consumption costs of each type of facility $(€)$ Source: Self made

\section{Maintenance costs}

They were calculated according to the methodology discussed. There are, on the one hand, common costs for any of the alternatives analyzed, some of which, such as costs of mechanical maintenance, daily operations temperature control of deposits and pool and corrective operations for assistance or unforeseen will be given by the cost / hour of the necessary personnel and for the hours that they are in the center and on the other hand, chemical maintenance costs, have a fixed price.

A major in the installation of biomass will have to be a person in charge of removing the fuel ashes weekly and it will be carried out in the thermal solar a monitoring plan (cleaning of panels and control of collectors and circuits) and maintenance of the accumulation and exchange systems, hydraulic circuit and electrical system that were estimated at $1.400 €$ / year for installation "Natural Gas" and $2.775 €$ / year for "Solar with Natural Gas" on the grounds that the maintenance cost of solar panels is $8.3 € / \mathrm{m} 2$ installation ( $25 € / \mathrm{h}$ would mean 56 and 111 hours per year, respectively). The overall maintenance costs are shown in Table 8 and shown in Table 8.1 of Annex 1

\begin{tabular}{|c|c|c|c|c|}
\hline & $\begin{array}{c}\text { Natural } \\
\text { gas } \\
\text { (NG) }\end{array}$ & $\begin{array}{c}\text { Biomass } \\
\text { (BM) }\end{array}$ & $\begin{array}{c}\text { Solar } \\
+ \text { GN }\end{array}$ & $\begin{array}{c}\text { Solar } \\
+ \text { BM }\end{array}$ \\
\hline $\begin{array}{c}\text { Annual } \\
\text { maintenance }\end{array}$ & 33,650 & 33,550 & 35,025 & 34,950 \\
\hline
\end{tabular}

Table 8 Maintenance costs of each type of installation base year $(€)$ Source: Self made

According to these costs, the "Solar with Natural Gas" installation is the one with highest maintenance costs, compared to "Biomass", the most economical. It remains to be seen whether the increased investment and maintenance costs of the "Solar with Natural Gas" installation are assumable to compensate with lower consumption cost.

\subsection{VAN analysis}

To estimate the VPN, the commented methodology and the formula included in table 9 Appendix 1 First, before applying the NPV, energy consumption (kwh) and the production of energy required was estimated to cover the claimed consumption depending on the performance of each type of installation. 
During a time horizon of 20 years as the average useful life of the facilities (Figure 2 and table 10 Appendix 1), applying the percentages of growth for SHW discussed in the methodology (50\% year 3, year 33\% $415 \% 5 \%$ 5 year year 6 ). From year 6 , the consumption of SHW number of users, and to make visual tables, columns 12 to 20 were removed, and put "10 and following (ss ) pairs" and "11 and following (ss)", understanding that there would be the same consumption alternately.

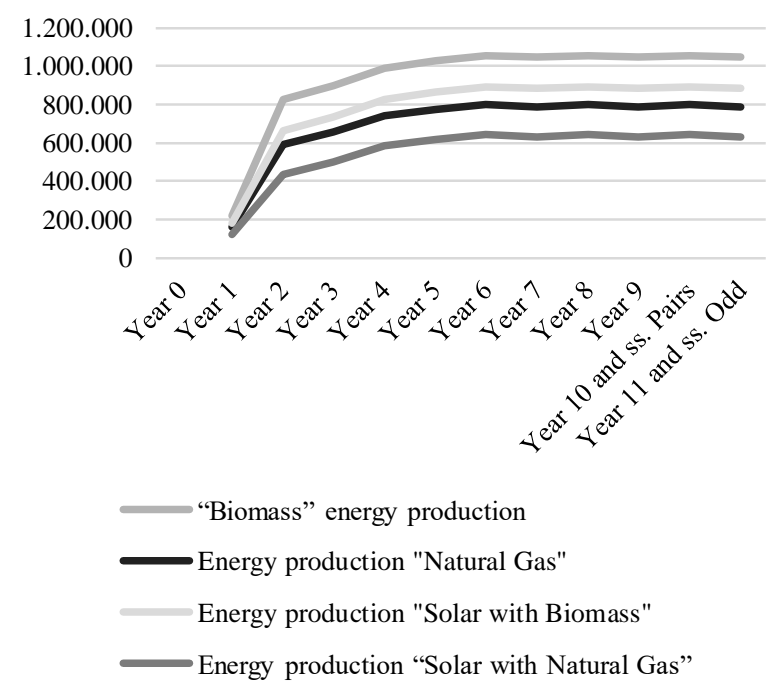

Graphic 2 Energy production of each type of installation (kWh)

Source: Self made

After the first filling swimming pools in October of 1 (opening) and filling of year 2 (calculation basis) only complete pools will be emptied when required repairs, and is usually emptied only a portion for minor repairs. As the business-case is a benchmark of quality and to anticipate potential repairs it was considered a commissioning every two years. The years when the pools are not empty, should take into account evaporation losses and radiation 72 hours excluded in the years that emptied itself. The annual energy consumption results are those listed in table 10 Appendix 1, ranging between $€ 203,127$ and a maximum of 982,194 in the 20 years considered. They suppose an increasing consumption until year 6 , from which there will be only small declines in the years when the pools are not emptied.

Based on the above data, and taking into account the performance of each type of boiler, energy producing and energy costs for each type of installation were calculated.
By adding the maintenance costs (equal for all years), the total annual costs of each installation were obtained. The total and disaggregated costs are shown in Tables 10.1 (Natural Gas), 10.2 (Biomass), 10.3 (Solar with Natural Gas) and 10.4 (Solar with Biomass) of Appendix 1.

From the initial investment and total costs, all negative as disbursements, the updated cash flows were obtained at $8.40 \%$ (discount rate according to the WACC formula). And by adding the discounted cash flows of each installation, the npvs of each of them were obtained. And by adding the discounted cash flows of each facility the NPV of each were obtained. In Tables 10.1, 10.2, 10.3 and 10.4 APPENDIX 1 all cash flows data that serve as the basis for calculations of VPN and Table 11 below, the results are collected.

\begin{tabular}{|c|c|}
\hline & Value $(€)$ \\
\hline NPV Natural Gas & $755,418.55$ \\
\hline NPV Biomass & $672,403.49$ \\
\hline Solar NPV with Natural Gas & $726,471.05$ \\
\hline NPV Solar Biomass & $719,968.79$ \\
\hline
\end{tabular}

Table 11 NPV values

Source: Self made

As shown in the above table, the NPV of greater value is the installation "Biomass" ( $€$ 672,403.49). Therefore, this type of installation will be the most convenient and profitable for the company. It is because, although "Biomass" has a low energy consumption slightly lower than "Natural Gas" and higher than the installations with voluntary solar contribution ("Solar with Natural Gas" and "Solar with Biomass"), these energy costs are compensated with an initial investment and with lower maintenance costs than other types of installation, due in large part to subsidies that considerably reduce their installation costs (Table 10.2 Appendix 1). Even if a higher pellet cost ( $€ 0.0366 / \mathrm{kwh}$ of the certified category A1 was used instead of the $€ 0.0359 / \mathrm{kwh}$ used as the average price) and gave a higher energy cost in the base year $(30,319, € 54$ versus $€$ 29,737.2), the NPV would remain the highest ($678,623.1 €$ ), compensating to spend a little more on the cost of producing energy than investing a very large amount in hybrid solar installations, since which will mean lower consumption and lower cash flows (tables 10.3 and 10.4 Appendix 1) but not enough to make the initial outlay better than "Biomass". 
The VPN closest to that of "Biomass" is that of "Solar with Biomass". Keep in mind that this installation has higher cash flows and therefore less costs, a difference that will be reduced over time, as it will increase the consumption of SHW with the influx of people, so that the difference will be reduced, and it presents a higher initial outlay and higher maintenance costs (table 10.4 APPENDIX 1). The way to finance the installation, except for subsidies, was not taken into account in the VPN analysis in order to see the VPN of the project itself.

\subsection{Environmental impact}

As mentioned, and according to the criteria of the Practical Guide for calculating emissions of greenhouse gases (ghgs) (Generalitat de Catalunya, 2011), it is considered that biomass and solar energy does not produce $\mathrm{CO} 2$ emissions at their stage of consumption, or they are hardly significant. However, natural gas does (2.15 kg / Nm3 emissions of $\mathrm{CO} 2$, considering that each represents $1 \mathrm{kwh} \mathrm{Nm} 3$ / $10.65 \mathrm{kwh}$ (Generalitat de Catalunya, 2011)). Therefore, the most sustainable installations would be those that use biomass (exclusively or combined with solar energy), followed by installations that use natural gas (combined with more solar energy than the mandatory or compulsory).

The implementation of the "Biomass" installation, the most appropriate for the business-case according to the financial feasibility analysis, is a neutral issue and, as can be seen in table 12 of APPENDIX 1, when opting for the installation "Biomass "against" Natural Gas with Solar", it is avoided to emit between $24,131.28 \mathrm{~kg}$ and 129,463, $92 \mathrm{~kg}$ of $\mathrm{CO} 2$ per year (minimum and maximum estimates) a and against the installation" Natural Gas" it is avoided to emit between $32,031.77$ and $161,065.48 \mathrm{~kg} \mathrm{~kg}$ of $\mathrm{CO} 2$ per year (minimum and maximum estimates). It is seen, therefore, that the $i$ installation "Biomass" pollutes less.

If $\mathrm{CO} 2$ emissions are valued economically according to the European Investment Bank (2013) method with a central estimate of the associated damage, it is obtained that they would be equal to $25+(2018-2010)$ $=€ 33 / \mathrm{t} \mathrm{CO} 2$.
Knowing this, the external environmental costs could be calculated by multiplying this figure by the $\mathrm{CO} 2$ emissions obtained in Table 13. As it has been seen, only the installations with Natural Gas will suppose emissions in the consumption stage, therefore, they will be the only ones that add external costs and the only ones that suffer modifications in their VPN that will suppose more negative flows (tables 14.1 and 14.2 of Appendix 1). According to this, the NPV of the "Natural Gas" and "Solar with Natural Gas" installation will be more negative and will continue to be lower than those of "Biomass" and "Solar with Biomass" (table 14). The installation chosen according to these NPV would continue to be "Biomass".

\begin{tabular}{|c|c|}
\hline & Value $(€)$ \\
\hline NPV Natural Gas & $-799,717.13$ \\
\hline NPV Biomass & $672,403.49$ \\
\hline Solar NPV with Natural Gas & 761549.2 \\
\hline NPV Solar Biomass & $719,968.79$ \\
\hline
\end{tabular}

Table 14 NPV values of external costs emCO2 issions Source: Self made

The implementation of the "Biomass" installation will mean environmental advantages for the business-case such as:

Optimal implementation of Corporate Social Responsibility (CSR), and to be aware for the proper performance of their activities

A competitive advantage oriented towards sustainable development by following an environmentally friendly energy management

Reducing pollutant emissions as fuels such as natural gas are composed of different harmful gases and by opting for biomass, less pollution is created.

However, despite this study focuses on emissions and environmental impact of the consumption stage, you should be aware that the environmental impact goes beyond and encompasses the entire life cycle of the fuel or power source (LCA) to be used. So, taking the account the whole life cycle, biomass could have some negative impact on the environment and be more sustainable hybrid installation "Solar with biomasa". 


\section{Conclusions}

Based on the above, and the present case, it could be concluded that the "biomass" installation is the most appropriate because: - It has the highest NPV of options
analyzed.

\begin{abstract}
Although the costs of energy consumption of hybrid installations "Solar with Natural Gas" and "Solar Biomass" are lower than those of "biomass", the high investments required by these installations are not offset by their costs of energy consumption or maintenance costs.
\end{abstract}

The study was based mainly on financial issues and environmental impacts in the consumption stage. Between "Biomass" exclusively or "Solar Biomass", the first option is the best financially, because, even if it has a higher consumption, it would be compensated with the reduced investment that it requires in front of a hybrid installation. Therefore, the "Biomass" installation would be the chosen one, since it requires less initial outlay than the other installations and, in addition, has reduced maintenance costs.

For future studies would be interesting to note if under different circumstances, such as other characteristics of the subsidies, applying another type of analysis, including risk factors or uncertainties or considering alternative installation of hot water and pool heating, the option of "biomass" would remain the most appropriate or optimal. Some methods to include risk considerations in the analysis could be to add a risk factor in the discount rate or to quantify the uncertainty through sensitivity analysis to present a range of possible outcomes varying assumptions of risk (Galán, Gonzalez Leal \& Varela, 1999).

At the environmental level, the consumption stage in which it has based the study, "Biomass" would also be the option chosen. However, it might be interesting to note the benefits of the hybrid system, combining two sources of renewable energy: solar and biomass.
In principle, both have less harmful emissions for the environment than the "Natural Gas" and "Solar with Natural Gas" installations but we see that "Biomass" has a greater need to produce more kwh of energy, not covered by solar contribution (table 12 Appendix 1).

In addition, although emissions at the consumption stage are neutral, they are not in the rest of the life cycle of the energy source therefore it could also be interesting to apply and study the usefulness of operational improvements in managing demand hot water needed to reduce consumption and analyze the environmental impact not only taking into account the emissions generated in the consumption phase, but throughout the life cycle because, in that case, the alternative choice might be different. A more sustainable option in this regard, which incorporates all externalities and environmental impact, despite assuming a higher investment cost, could be the "Solar with Biomass" alternative because with the solar contribution the saving in energy use would reduce the impact environmental, preserving non-renewable resources, avoiding the generation of more energy, not requiring the consumption of so many pellets and reducing the carbon footprint.

In short, implementing installations in which renewable energy and sustainability prevail will help companies to differentiate themselves, as actions that affect their corporate social responsibility associated with the conservation of the environment, taking into account not only growth and economic savings but also the social and environmental impact (Martí, 2012). Betting on energy such as biomass, solar or combined in hybrid systems, can be positive since it contributes to greater long-term economic savings and lower emissions in the energy consumption stage, but we must move forward to take into account not only economic and environmental aspects impact on the consumption stage, but in general

\section{References}

Albarracin, E .; Sanabria, J .; Maíllo, A. (2007). Energy savings in indoor pools. Ciatesa. Retrieved June 2018 from http://www.marioloureiro.net/tecnica/eficiencia Energ/19-B.EvaMAlbarracinCIATESA.pdf 
Artuso, P .; Santiangeli, A. (2008). Energy solutions for sports facilities. International Journal of Hydrogen Energy, 33 (12), 31823187.https://doi.org/10.1016/j.ijhydene.2007.12 .064

ATECYR. Spanish Technical Association of Air Conditioning and Refrigeration (2011). technical guide central hot water. Madrid Spain. ATECYR for the Institute for Diversification and Saving of Energy (IDEA). Retrieved June 2018 from http: // www.idae.es / publications / guide-tecnica-hot-water-plant-health

AuroPro3.0.1. Vaillant program.

Bernow, SS and Brown, DB, 1990, "Valuation of Environmental Externalities for Energy Planning and Operations" Tellus Institue, Boston.

Britain, E. (2007). Technical and economic study of the installation of a biomass plant electricity generation. PFC. Universidad Pontificia Comillas. Madrid Spain. Retrieved June 2018 from https: // is.scribd.com / document / 207150775 / plant-biomass-pdf

Cloquell, V .; Artacho, M .; Santamarina, C. (2009). Improving energy efficiency of a sports complex through the management of their electricity consumption. XIII International Congress of Project Engineering in Badajoz. Polytechnic university of Valencia. Retrieved June 2018 from http: // www.aeipro.com / files / congress / 2009badajoz / ciip09_1100_1109.2552.pdf

Chakrabarty, S., \& Islam, T. (2011). Financial viability and eco-efficiency of the solar home systems (SHS) in Bangladesh. Energy, 36 (8), 4821-4827.https://doi.org/10.1016/j.energy.2011.05.016

Condori Yucra, R. (2010). Study for pool heating and domestic hot water (DHW) solar energy UNAP. IV Latin American Conference on Solar Energy and XVII Peruvian Symposium of Solar Energy (XVII - SPES), Cusco, Peru. Retrieved June 2018 from https://is.slideshare.net/robvaler/exposure-ivclaexviispes 2010
Ministry of Economy and Technological Innovation. Directorate General of Industry, Energy and Mines (2005): Measures for energy efficiency in energy-saving Guide gym (Chapter 02). Madrid. Ministry of Economy and Technological Innovation. Retrieved June 2018 from http: // www.madrid.org / bvirtual / BVCM005515.pdf

Corral, D. (2011) Project for a solar thermal energy in the sports Can Xarau of Cerdanyola del Valles. PFC. Polytechnic University of Catalonia. Barcelona. Retrieved June 2018 from https: // UPCommons.upc.edu / handle / 2099.1 $/ 11530$ ? locale $=$ en-attribute

Creara. Specialists in energy saving and efficiency (2011) Energy Audit of municipal offices. Municipal energy plan optimization. City of Jerez de la Frontera. Retrieved June 2018 from http://www.jerez.es/fileadmin/contratacion/POEM\% 20Jerez\% 202011/4\% 20Dependencias\% 20municipales/Chair/Resumen_PRESIDENCIA.pdf

Dhavale, D., \& Sarkis, J. (2015). Integrating Carbon Market Uncertainties into a sustainable manufacturing investment decision: a Bayesian approach NPV. International Journal of Production Research, 53 (23), 7104-7117. https://doi.org/10.1080/00207543.2015.1018450

Delacámara, G. (2008). Guide for Policy Makers - Economic analysis of environmental externalities. German Agency for Technical Cooperation. UN.CEPAL. Project documents 200.Retrieved February 2019 from https://repositorio.cepal.org/handle/11362/3624

Endesa (2018). Tarifa Gas Companies 3.4: $0.048796 € / \mathrm{kWh}$ and fixed term of $80.97 € /$ month until 04/15/2018. Retrieved from 2018 https://www.endesaclientes.com/companies/rate -gas-empresas.html

Escobar, GJ (2009): Manual of energy efficiency for SMEs. 04. Sport Centers. CNAE 93.1. Manual energy efficiency for SMEs (pp.91-118). Gas Natural Fenosa and EOI Business School. Retrieved June 2018 from https: // docplayer.com / 5926169-Manual-deenergyefficiency-to-SME-centers-sports-

CNAE- 93-1.html 
European Commission (1995). DGXII, Science, Research and Development, JOULE (1995). Externalities of Fuel Cycles 'ExternE' Project. Report 2 Methodology.

European Commission (1999). ExternE Externalities of Energy. Vol 7 - Methodology Update. A Report produced for the EC - DG XII, Office of Publications for the European Communities, Luxembourg.

European Investment Bank (2013). The Economic Appraisal of Investment Projects at the EIB. Retrieved February 2019 from https://www.eib.org/attachments/thematic/econ omic_appraisal_of_investment_projects_en.pdf

Fraguas Herrero, A. (2010). Sport Commitment to Sustainable Development. Green Cross Spain. CONAMA10 National Environmental Congress. Retrieved June 2018 fromhttp://www.conama10.conama.org/conama 10/download/files/CT\%202010/41011.pdf

Municipal Sports Foundation (2011). Maintenance Manual Sports. Retrieved June 2018 from https://www.diba.cat/documents/41289/662996 0/Manual+mantenimiento+2011.pdf/45d492633eef-4d1d-9611-629a16d8f173

Galan, A .; González, R .; Leal, J .; Varela, M. (1999). Cost-benefit analysis of a Biomass Power Plantin Morocco and Algeria in a Photovoltaic Installation. 886. Technical Report Ciemat Institute of Energy Studies. Retrieved June 2018 from https://inis.iaea.org/collection/NCLCollectionSt ore/_Public/30/038/30038694.pdf

Generalitat de Catalunya (2011). PRACTICAL GUIDE FOR THE CALCULATION OF EMISSIONS OF GREENHOUSE GASES (GHG). Retrieved February 2018 from http://www.caib.es/sacmicrofront/archivopub.d o?ctrl=MCRST234ZI97531\&id=97531

Hohmeyer, O. (1988). Social Costs of Energy Consumption. External Effects of Electricity Generation in the Federal Republic of Germany. Springer-Verlag Berlin Heidelberg. https://doi.org/10.1007/978-3-642-83499-8
IDEA (2019). EMISSIONS. Retrieved February 2019 from https://www.idae.es/tecnologias/energiasrenovables/uso-termico/biomasa/emisiones

I (Institute for Diversification and Saving of Energy) (2018). Report liberalized energy prices in the 4th quarter 2017. Retrieved June 2018 from

http://www.idae.es/sites/default/files/estudios_i nformes_y_estadisticas/informe_precios_bioma sa_usos_termicos_4t_2017_3.pdf

Infrastructure Sustainability Council of Australia (ISCA) (2016). Developing a Business Case for Sustainability Initiatives in Infrastructure: A 'How To' Guide Page. Retrieved June 2018 from http://www.isca.org.au/getmedia/effcfa61-053a462e-8918-

1f5af3fbef53/BusinessCaseHowTo_231610_FI NALFORPUBLISHING.aspx

Karmokolias, Y. (1996). Cost benefit analysis of private sector, environmental investments: a case study of the Kunda cement factory (Inglés). IFC discussion paper no. IFD 30, IFC working paper series. Washington, DC: The World Bank. Retrieved June 2018 from http://documents. worldbank.org/curated/en/548 121468770728632/Cost-benefit-analysis-ofprivate-sector-environmental-investments-acase-study-of-the-Kunda-cement-factory

Linares Llamas, P. (2002). Externalities of energy and valuation. Energy, taxation and the environment in Spain. Alberto Gago Rodríguez (ed.), Xavier Labandeira Villot (dir.). ISBN 848008-111-2, pp. 63-84.Retrieved February 2019 from

https://www.iit.comillas.edu/pedrol/documents/ gago02.pdf

Nikolaidis, P., Chatzis, S., \& Poullikkas, A. (2018). Renewable energy integration through optimal unit commitment and electricity storage in weak power networks. International Journal of Sustainable Energy 1-17. https://doi.org/10.1080/14786451.2018.1516669 
Noguera, J. (2011): Air-conditioning an indoor pool by combining solar thermal energy, geothermal energy and biomass boiler support. Màster Interuniversitari UB-UPC d'Enginyeria into energy. Polytechnic University of Catalonia. Barcelona, Spain. Retrieved June 2018 from https: // UPCommons.upc.edu / bitstream / handle / 2099.1 / 12795 / Memoria.pdf? sequence $=1 \&$ isAllow ed $=\mathrm{y}$

Martí, DC (2012). Financial and environmental evaluation of using electric vehicles in companies for the distribution process. Grade work of St. Bonaventure University in Bogota.Retrieved June 2018 from https://docplayer.es/2549718-Evaluacion-

financiera-y-ambiental.html

Martinez Sanchez, D (2011). Comparative study on energy efficiency in residential building with a system of micro thermal energy and electricity compared to conventional systems. Thesis. d'edificació Polytechnic School of Barcelona. EPSEB. CPU. Barcelona, Spain. Retrieved June 2018 from https: // UPCommons.upc.edu / handle / 2099.1 / 10909

Moreno, F. (2012). Technical and economic study for replacement of diesel thermal biomass in urban buildings. Thesis. Higher Technical School of Mining and Energy of the University of Madrid. Madrid Spain. Retrieved June 2018 from http://oa.upm.es/14999/

Technical Regulations Document HE4 the Captcha code (CTE). Energy saving. Recovered from

https://www.codigotecnico.org/images/stories/p df/ahorroEnergia/DccHE.pdf Retrieved June 2018 welfare and hygiene Demanding IT 1.1 of Royal Decree 1027/2007 of 20 July.

Ottinger, RL, Wooley, DR, Robinson, NA, Hodas, DR and Babb, SE (1991). Environmental Costs of Electricity. Pace University, Center for Environmental Legal Studies, Oceana Publications, New York.

Pearce, D .; Bann, C .; Georgiou, S. (1992). The social cost of fuel cycles. Center for Social and Economic Research on the Global Environment, London (United Kingdom). ISBN: 0114142882.
Regulation of Thermal Installations in Buildings (RITE). NIDE 3: Pools. Royal Decree 314/2006 of 17 March, Technical Building Code (CTE). UNE 94002: 2005 Solar heating systems for hot water. AENOR.

Turner, RK, Georgiou, S., Brouwer, A. Bateman, and Langford IJ, IJ (2003) "Towards an integrated environmental assessment for wetland and catchment management", The Geographical Journal 169 (2): 99-116. https://doi.org/10.1111/1475-4959.04953

\section{Appendix 1}

\begin{tabular}{|c|c|c|c|}
\hline $\begin{array}{l}\text { Swimming } \\
\text { courses }\end{array}$ & $\begin{array}{l}\text { Sessions / } \\
\text { week }\end{array}$ & $\begin{array}{l}\text { Users / } \\
\text { session }\end{array}$ & $\begin{array}{l}\text { User / } \\
\text { month }\end{array}$ \\
\hline Type 1 & 29 & 5 & 580 \\
\hline type 2 & 18 & 10 & 720 \\
\hline type 3 & 12 & 240 & 960 \\
\hline type 4 & 40 & 8 & 1280 \\
\hline Total & 107 & & 3,540 \\
\hline $40 \%$ Year 2 & & & 1,416 \\
\hline Racket courses & $\begin{array}{lll}\begin{array}{l}\text { Grades } \\
\text { /week }\end{array} & 1 & \text { h } \\
\end{array}$ & $\begin{array}{ll}\begin{array}{l}\text { Users } \\
\text { course }\end{array} & / \\
\end{array}$ & $\begin{array}{ll}\text { User } \\
\text { month }\end{array}$ \\
\hline Tennis & 8 & two & 64 \\
\hline paddle & 12 & 4 & 192 \\
\hline Total & twenty & 6 & 256 \\
\hline $40 \%$ Year 2 & & & 102 \\
\hline Arts courses & $\begin{array}{ll}\begin{array}{l}\text { Sessions } \\
\text { week }\end{array} & / \\
\end{array}$ & users & users \\
\hline martial & & /session & /month \\
\hline Total & twenty-one & twenty & 1680 \\
\hline $40 \%$ Year 2 & & & 672 \\
\hline & & \multicolumn{2}{|c|}{ User / month } \\
\hline Tracks & & \multicolumn{2}{|l|}{158} \\
\hline & & \multicolumn{2}{|l|}{ User / month } \\
\hline Free admission & & \multicolumn{2}{|l|}{10} \\
\hline & & \multicolumn{2}{|l|}{ User / month } \\
\hline Swimming pool & & \multicolumn{2}{|l|}{1,200} \\
\hline & & \multicolumn{2}{|l|}{ User / month } \\
\hline fitness & & \multicolumn{2}{|l|}{5,300} \\
\hline \multirow[t]{2}{*}{ Guided activities } & $\begin{array}{l}\text { Weekly } \\
\text { sessions }\end{array}$ & users & users / \\
\hline & $1 \mathrm{~h}$ & /session & Month \\
\hline room 1 & 16 & 17 & 1,088 \\
\hline room 2 & 37 & 17 & 2,516 \\
\hline room 3 & 40 & 17 & 2,720 \\
\hline room 4 & 40 & 17 & 2,720 \\
\hline Total & & & 9,044 \\
\hline $40 \%$ Year 2 & & & 3617.6 \\
\hline $\begin{array}{l}\text { Total Monthly } \\
\text { Uses }\end{array}$ & & & 12,476 \\
\hline
\end{tabular}

Table 2.1 Monthly Inflow in Year 2 with $40 \%$ coverage of the maximum number of people and $100 \%$ of the inflow to the center.

Source: Self made 


\begin{tabular}{|c|c|c|c|c|c|c|c|}
\hline Year 2 & $\begin{array}{l}\text { Uses / } \\
\text { Month }\end{array}$ & January & February & March & April & May & June \\
\hline $\begin{array}{l}\text { Influx to } \\
\text { the Sports } \\
\text { Center }\end{array}$ & $100 \%$ & $80 \%$ & $90 \%$ & $90 \%$ & $100 \%$ & $100 \%$ & $90 \%$ \\
\hline courses & 2,190 & 1,752 & 1,971 & 1,971 & 2,190 & 2,190 & 1,971 \\
\hline Tracks & 158 & 126 & 142 & 142 & 158 & 158 & 142 \\
\hline $\begin{array}{l}\text { Free } \\
\text { admission }\end{array}$ & 10 & 8 & 9 & 9 & 10 & 10 & 9 \\
\hline $\begin{array}{l}\text { Swimming } \\
\text { pool }\end{array}$ & 1,200 & 960 & 1,080 & 1,080 & 1,200 & 1,200 & 1,080 \\
\hline fitness & 5,300 & 4,240 & 4,770 & 4,770 & 5,300 & 5,300 & 4,770 \\
\hline Rooms & 3,618 & 2,894 & 3,256 & 3,256 & 3,618 & 3,618 & 3,256 \\
\hline $\begin{array}{l}\text { TOTAL } \\
\text { (Users) }\end{array}$ & 12,476 & 9,981 & 11,228 & 11,228 & 12,476 & 12,476 & 11,228 \\
\hline Year 2 & $\begin{array}{l}\text { Uses / } \\
\text { month }\end{array}$ & July & August & September & October & November & December \\
\hline $\begin{array}{l}\text { Influx to } \\
\text { the Sports } \\
\text { Center }\end{array}$ & $100 \%$ & $70 \%$ & $40 \%$ & $80 \%$ & $90 \%$ & $100 \%$ & $80 \%$ \\
\hline courses & 2,190 & 1,533 & 876 & 1,752 & 1,971 & 2,190 & 1,752 \\
\hline Tracks & 158 & 111 & 63 & 126 & 142 & 158 & 126 \\
\hline $\begin{array}{l}\text { Free } \\
\text { admission }\end{array}$ & 10 & 7 & 4 & 8 & 9 & 10 & 8 \\
\hline $\begin{array}{l}\text { Swimming } \\
\text { pool }\end{array}$ & 1,200 & 840 & 480 & 960 & 1,080 & 1,200 & 960 \\
\hline fitness & 5,300 & 3,710 & 2,120 & 4,240 & 4,770 & 5,300 & 4,240 \\
\hline Rooms & 3,618 & 2,533 & 1,447 & 2,894 & 3,256 & 3,618 & 2,894 \\
\hline $\begin{array}{l}\text { TOTAL } \\
\text { (Users) }\end{array}$ & 12,476 & 8,733 & 4,990 & 9,981 & 11,228 & 12,476 & 9,981 \\
\hline
\end{tabular}

Table 2.2 Monthly Inflow Year 2 as percentages of affluence center

Source: Self made

\begin{tabular}{|c|c|c|c|c|c|}
\hline & $\begin{array}{c}\text { Installed } \\
\text { power } \\
(k W)\end{array}$ & $\begin{array}{l}\text { Operating } \\
\text { hours per } \\
\quad \text { day }\end{array}$ & $\begin{array}{c}\text { Days } \\
a \\
\text { year }\end{array}$ & $\begin{array}{c}\text { Total } \\
\text { hours / } \\
\text { year }\end{array}$ & $\begin{array}{c}\text { Energy } \\
\text { consumption } \\
(k W h) \\
\text { annually }\end{array}$ \\
\hline $\begin{array}{l}\text { Total } \\
\text { evaporation } \\
\text { power }\end{array}$ & 63.22 & & & 4816 & $304,486.95$ \\
\hline pool 1 & 44.66 & - & - & 4816 & $215,060.72$ \\
\hline pool 2 & \begin{tabular}{|l|}
18.57 \\
\end{tabular} & & & 4816 & 89426.23 \\
\hline $\begin{array}{l}\text { Total } \\
\text { radiation } \\
\text { power }\end{array}$ & 6.62 & 24 & 362 & 8,688 & 57476.09 \\
\hline pool 1 & 5.38 & 24 & 362 & 8,688 & 46751.63 \\
\hline pool 2 & 1,23 & 24 & 362 & 8,688 & 10724.46 \\
\hline $\begin{array}{l}\text { Convection } \\
\text { power }\end{array}$ & 0 & - & - & & \\
\hline $\begin{array}{l}\text { Total power } \\
\text { per } \\
\text { transmission }\end{array}$ & $\mid 13.91$ & 24 & 365 & 8,760 & $121,834.08$ \\
\hline pool 1 & $\mid 11.1$ & 24 & 365 & 8,760 & 97236.00 \\
\hline pool 2 & 2,81 & 24 & 365 & 8,760 & 24598.08 \\
\hline $\begin{array}{l}\text { Total } \\
\text { renovation } \\
\text { Water power }\end{array}$ & 29.53 & 24 & 365 & 8,760 & $258,718.57$ \\
\hline pool 1 & 25.68 & 24 & 365 & 8,760 & $224,931.25$ \\
\hline pool 2 & 3.86 & 24 & 365 & 8,760 & 33787.32 \\
\hline ACS power & 71.05 & 5.8 & 365 & $2,115.54$ & $150,309.12$ \\
\hline $\begin{array}{l}\text { Total system } \\
\text { capacity } \\
\text { made }\end{array}$ & 196.89 & & & 72 & 14176.36 \\
\hline pool 1 & 171.18 & & & 72 & 12325.00 \\
\hline pool 2 & 25.71 & & & 72 & $1,851.36$ \\
\hline \multicolumn{5}{|c|}{ TOTAL } & $907,001.17$ \\
\hline \multirow{2}{*}{\multicolumn{5}{|c|}{$\begin{array}{l}\text { Saving heat exchanger (Table 46.1) } \\
\text { TOTA Laving exchanger }\end{array}$}} & $136,586.72$ \\
\hline & & & & & $770,414.45$ \\
\hline
\end{tabular}

Table 4.1 Power, operating hours per day, days per year and energy consumed in the base year calculation

\begin{tabular}{|c|c|c|c|}
\hline You & $\begin{array}{l}\text { Natural gas (with contribution Sol } \\
\text { Concept }\end{array}$ & $€ /$ ud. & Total \\
\hline one & $300 \mathrm{~kW}$ boiler & 17,000 & 17,000 \\
\hline 32 & Solar panels for ACS minimum & 778 & 24,896 \\
\hline 39 & Minimum Solar panels for pool & 778 & 30342 \\
\hline 36 & Support for 2 panels & 109 & 3,924 \\
\hline two & Accumulator 2500 liters & 5,772 & 11,544 \\
\hline one & Accumulator 1500 liters & 4,362 & 4,362 \\
\hline one & Heat exchangers water-water & 2,049 & 2,049 \\
\hline one & hydraulic equipment & 6,000 & 6,000 \\
\hline one & Electric material & 4,500 & 4,500 \\
\hline one & Isolating material & 4000 & 4000 \\
\hline one & Labor and commissioning & 12,000 & 12,000 \\
\hline \multirow[t]{5}{*}{ one } & Transportation to work & 4,250 & 4,250 \\
\hline & & Natural gas & 30971 \\
\hline & & Solar & 93896 \\
\hline & & Total & 124867 \\
\hline & Biomass & & \\
\hline You & Concept & $€ /$ ud. & Total \\
\hline one & $300 \mathrm{~kW}$ boiler & 55510 & 55510 \\
\hline one & Accumulator 2500 liters & 5,772 & 5,772 \\
\hline one & Fuel storage silo & 17,500 & 17,500 \\
\hline one & Heat exchangers water-water & 2,049 & 2,049 \\
\hline one & hydraulic equipment & 4,628 & 4,628 \\
\hline one & Electric material & 2500 & 2,500 \\
\hline one & $\begin{array}{lll}\begin{array}{l}\text { Gas cleaning } \\
\text { insulation }\end{array} & \text { system } & \text { with } \\
\end{array}$ & 7153 & 7.153 \\
\hline one & Power system & 5563 & 5,563 \\
\hline one & $\begin{array}{l}\text { Automatic discharge device ash } \\
\text { and ash deposit }\end{array}$ & 5160 & 5,160 \\
\hline one & Construction and commissioning & 6000 & 6,000 \\
\hline \multirow[t]{5}{*}{ one } & Transportation to work & 1800 & 1,800 \\
\hline & & \begin{tabular}{|l} 
Total biomass \\
\end{tabular} & 113635 \\
\hline & & Grant Inega & 56,818 \\
\hline & & Total & 56,818 \\
\hline & Natural gas Solar Voluntary Con & tribution (plus Requirec & \\
\hline You & Concept & $€ /$ ud. & Total \\
\hline 40 & Solar panels for ACS & 778 & 31,120 \\
\hline 102 & Solar panels for pool & 778 & 79356 \\
\hline 71 & Support for 2 panels & 109 & 7,739 \\
\hline one & $300 \mathrm{kw}$ Natural gas boiler & 17,000 & 17,000 \\
\hline 3 & Accumulator 2500 liters & 5,772 & 17,316 \\
\hline one & Accumulator 300 liters & 1,363 & 1,363 \\
\hline one & Heat exchangers water-water & 2,049 & 2,049 \\
\hline one & hydraulic equipment & 10,800 & 10,800 \\
\hline one & Electric material & 8,100 & 8,100 \\
\hline one & Isolating material & 7,200 & 7,200 \\
\hline one & Labor and commissioning & 21,600 & 21,600 \\
\hline \multirow[t]{7}{*}{ one } & Transportation to work & 7,650 & 7,650 \\
\hline & & Total Natural Gas & 30971 \\
\hline & & Total Solar & 180322 \\
\hline & & Total & 211293 \\
\hline & & \begin{tabular}{|l} 
grant Inega \\
\end{tabular} & 60,000 \\
\hline & & Total & 151293 \\
\hline & Biomass Solar voluntary con & n (equal to mandator & \\
\hline You & Concept & $€ /$ ud. & Total \\
\hline 71 & Solar panels for ACS & 778 & 55238 \\
\hline 36 & Support for two panels & 109 & 3,924 \\
\hline one & $\begin{array}{l}300 \mathrm{kw} \text { Biomass boiler } \\
\text { Policombustible }\end{array}$ & 55510 & 55510 \\
\hline two & Accumulator 2500 liters & 5,772 & 11,544 \\
\hline one & Accumulator 1500 liters & 4,362 & 4,362 \\
\hline one & Fuel storage silo & 14,000 & 14,000 \\
\hline one & Heat exchangers water-water & 2,049 & 2,049 \\
\hline one & $\begin{array}{l}\text { Gas cleaning } \\
\text { insulation }\end{array}$ & 7.153 & 7.153 \\
\hline one & Power system & 5,563 & 5,563 \\
\hline one & $\begin{array}{l}\text { Automatic discharge device ash } \\
\text { and ash deposit }\end{array}$ & 5,160 & 5,160 \\
\hline one & hydraulic equipment & 9,428 & 9,428 \\
\hline one & Electric material & 6,100 & \begin{tabular}{|l|}
6,100 \\
\end{tabular} \\
\hline one & Isolating material & 3,200 & 3,200 \\
\hline one & Construction and commissioning & 15,600 & 15,600 \\
\hline \multirow[t]{6}{*}{ one } & Transportation to work & 5,200 & 5,200 \\
\hline & & biomass & 110135 \\
\hline & & Solar & 93896 \\
\hline & & $\begin{array}{|ll|}\text { TOTAL } & \text { Solar } \\
\text { Biomass }\end{array}$ & 204031 \\
\hline & & grant Inega & 60,000 \\
\hline & & $\begin{array}{l}\text { TOTAL with Grant } \\
\text { Inega }\end{array}$ & 144031 \\
\hline
\end{tabular}

Table 5 Cost of each type of installation 


\begin{tabular}{|c|c|}
\hline & Nat \\
\hline $\begin{array}{l}\begin{array}{l}\text { Annual energy } \\
\text { exchanger }(\mathrm{kWh})\end{array} \\
\text { exconsumption }\end{array}$ & $770,414.45$ \\
\hline $\begin{array}{l}\text { Solar minimum mandatory contribution to } \\
\text { ACS }(40 \%) \text { and pools }(12 \%)(\mathrm{kWh})\end{array}$ & $152,444.87$ \\
\hline boiler Natural gas consumption (kWh) & $617,969.58$ \\
\hline $\begin{array}{l}\text { to produce actual boiler efficiency } 104 \% \\
\text { energy }(\mathrm{kWh})\end{array}$ & $594,201.52$ \\
\hline Price Natural Gas $(€ /$ kWh $)$ & 0.048796 \\
\hline fixed monthly cost & 80.97 \\
\hline Annual Natural Gas Cost & $29,966.30 €$ \\
\hline & biomass \\
\hline $\begin{array}{lccc}\begin{array}{l}\text { Annual } \\
\text { exchanger }(k W h)\end{array} & \text { consumption } & \text { savings } \\
\end{array}$ & $770,414.45$ \\
\hline $\begin{array}{l}\text { Energy to produce } 93 \% \text { boiler efficiency } \\
\text { (kWh) }\end{array}$ & $828,402.63$ \\
\hline Pellets Bulk price $(€ /$ kWh $)$ & 0.0359 \\
\hline Ann & $29,739.65 €$ \\
\hline & $\begin{array}{c}\text { Solar } \\
\text { combined }\end{array}$ \\
\hline $\begin{array}{llll}\begin{array}{l}\text { Annual } \\
\text { exchanger }(k W h)\end{array} & \text { energy } & \text { consumption } & \text { savings } \\
\end{array}$ & $770,414.45$ \\
\hline & $\begin{array}{l}\text { Solar with } \\
\text { Natural Gas }\end{array}$ \\
\hline $\begin{array}{l}\text { Solar Mandatory contribution to ACS }(40 \%) \\
\text { and Pool }(12 \%)(\mathrm{kWh})\end{array}$ & $152,444.87$ \\
\hline $\begin{array}{l}\text { Solar Voluntary contribution to ACS }(10 \%) \\
\text { and Pool }(20 \%)(\mathrm{kWh})\end{array}$ & $162,799.49$ \\
\hline Boiler Natural gas consumption ( $\mathrm{kWh})$ & $455,170.09$ \\
\hline $\begin{array}{l}\text { To produce actual boiler efficiency } 104 \% \\
\text { energy }\end{array}$ & $437,663.55$ \\
\hline Price Natural Gas $(€ / \mathrm{kWh})$ & 0.048796 \\
\hline fixed monthly cost & 80.97 \\
\hline Annual cost Solar + Natural Gas (€) & $22,327.87 €$ \\
\hline & $\begin{array}{c}\text { Solar } \\
\text { Biomass }\end{array}$ \\
\hline $\begin{array}{l}\text { Solar Voluntary contribution to ACS }(40 \%) \\
\text { and swimming pool }(30 \%)(\mathrm{kWh})\end{array}$ & $152,444.87$ \\
\hline Biomass boiler consumption (kWh) & $617,969.58$ \\
\hline to produce actual boiler efficiency $93 \%$ energy & $664,483.42$ \\
\hline Pellets Bulk price $(€ /$ kWh $)$ & 0.0359 \\
\hline 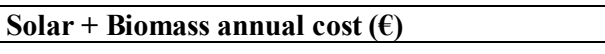 & 23, \\
\hline
\end{tabular}

Table 7.1 Energy costs of each type of facility

\begin{tabular}{|l|l|l|c|c|}
\hline & \multicolumn{1}{|c}{$\begin{array}{c}\text { Natural } \\
\text { gas }(\text { NG) }\end{array}$} & \multicolumn{1}{c|}{$\begin{array}{c}\text { Biomass } \\
(\text { NM) }\end{array}$} & \multicolumn{1}{c|}{$\begin{array}{c}\text { Solar }+ \\
\text { GN }\end{array}$} & $\begin{array}{c}\text { Solar + } \\
\text { BM }\end{array}$ \\
\hline $\begin{array}{l}\text { Annual } \\
\text { maintenance }\end{array}$ & $\begin{array}{l}33,650.00 \\
€\end{array}$ & $33,550 €$ & 35,025 & 34,950 \\
\hline
\end{tabular}

\begin{tabular}{|c|c|c|c|}
\hline Concept & $\begin{array}{l}\text { Working h / } \\
\text { year }\end{array}$ & $\boldsymbol{\epsilon} / \mathbf{h}$ & $\begin{array}{l}€ \text { per } \\
\text { year }\end{array}$ \\
\hline $\begin{array}{l}\text { Monthly Preventative } \\
\text { operations }\end{array}$ & 120 & 25 & 3,000 \\
\hline Daily operations & 730 & 25 & 18,250 \\
\hline Corrective operations & 200 & 25 & 5,000 \\
\hline $\begin{array}{l}\text { Common mechanical } \\
\text { maintenance (1) }\end{array}$ & 1050 & 25 & 26,250 \\
\hline $\begin{array}{l}\text { Maintenance } \\
\text { Chemical (2) }\end{array}$ & & & 6,000 \\
\hline $\begin{array}{l}\text { Biomass weekly Ash } \\
\text { Removal (3) }\end{array}$ & 52 & 25 & 1,300 \\
\hline $\begin{array}{l}\text { Thermal Solar: } \\
\text { Maintenance panels } \\
\text { (4) }\end{array}$ & 56 & 25 & 1400 \\
\hline $\begin{array}{l}\text { Thermal Solar: } \\
\text { Maintenance panels } \\
\text { (5) }\end{array}$ & 111 & 25 & 2,775 \\
\hline
\end{tabular}

Maintenance cost of Natural Gas: (1) + (2) + (4)

Biomass maintenance cost: $(1)+(2)+(3)$

Maintenance Cost Solar Natural Gas: (1) + (2) + (5)

Solar maintenance cost Biomass: (1) + (2) + (3) + (4)

Table 8.1 Maintenance costs of each type of installation base year

$$
\mathrm{VAN}=\sum_{t=1}^{n} \frac{V_{t}}{(1+k)^{t}}-I_{0}
$$

Where

Vt: Cash Flow represents in each period t.

I0: The value of the initial investment outlay (year 0)

NIs the number of periods considered.

$\mathbf{K}$ : Is the discount rate $=8.40 \%=$ WACC (Weighted Average Cost of Capital)

$$
W A C C(c p p)=K_{e} \frac{C A A}{C A A+D}+K_{d}(1-T) \frac{D}{C A A+D}
$$

Where:

\section{WACC: $\mathbf{8 . 4 0 \%}$}

Ke: Rate opportunity cost of shareholders (must be greater than $\mathrm{Kd}$ )

CAA: Capital contributed by shareholders for the establishment of sports center

D: outstanding indebtedness

kd:Cost of financial debt (having various types was a weighted average)

\begin{tabular}{|c|c|c|c|}
\hline$C A A$ & $2,340,000 €$ & .5526 & $C A A /(C A A+D)$ \\
\hline$D$ & $1,894,635 €$ & .4474 & $\mathrm{D} /(\mathbf{D}+\mathrm{CAA})$ \\
\hline$T$ & 0.25 & $0.0604(1)$ & $\mathrm{Ke} * \mathrm{CAA} /(\mathrm{CAA}+\mathrm{D})$ \\
\hline$K e$ & $10.93 \%$ & $0.0236(2)$ & $\begin{array}{l}\mathrm{Kd} *(\mathrm{D} / \mathrm{D}+\mathrm{CAA}) * \\
(1-\mathrm{T})\end{array}$ \\
\hline$k d$ & $7.03 \%$ & $8.40 \%$ & $(1)+(2)=$ WACC \\
\hline
\end{tabular}

T: Tax rate

Table 9 Formula NPV and WACC 


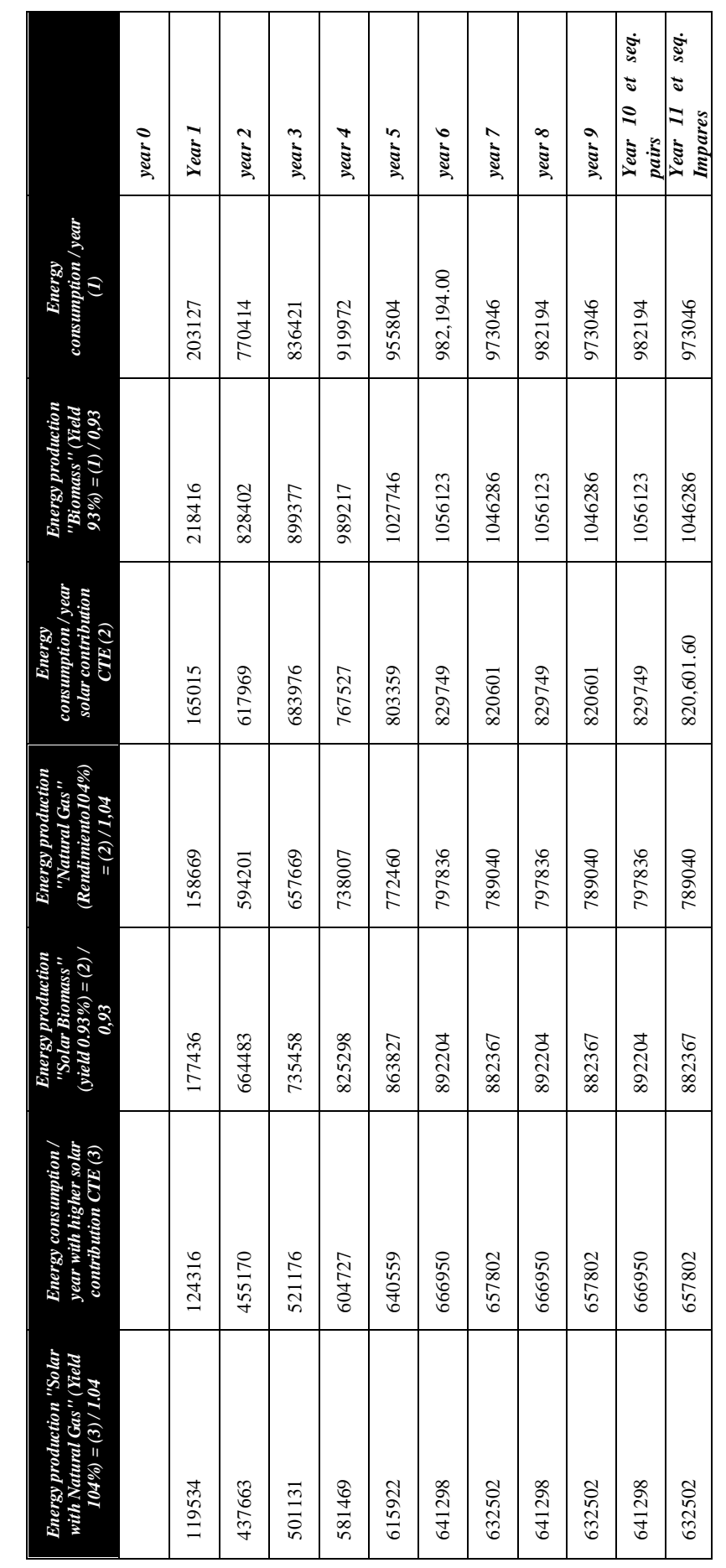

Table 10 Summary of energy consumption (kWh) for each type of installation and cash flows to calculate the NPV

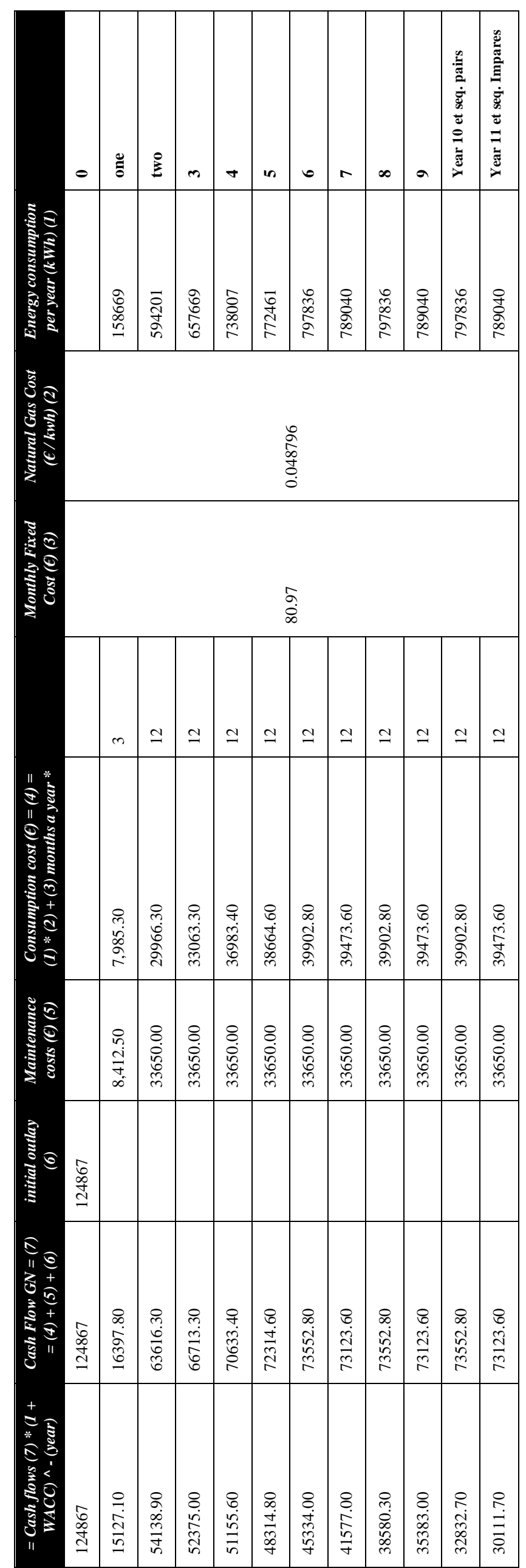

Table 10.1 Summary of total costs $(€)$ broken down for installation of Natural Gas and cash flows to calculate the NPV

LONGARELA-ARES, Angeles. Financial viability and environmental aspects in the selection of energy sources for sanitary hot water (SHW) and heated swimming pools. ECORFAN Journal-Mexico. 2019 
December 2019 Vol.10 No.23 46-71

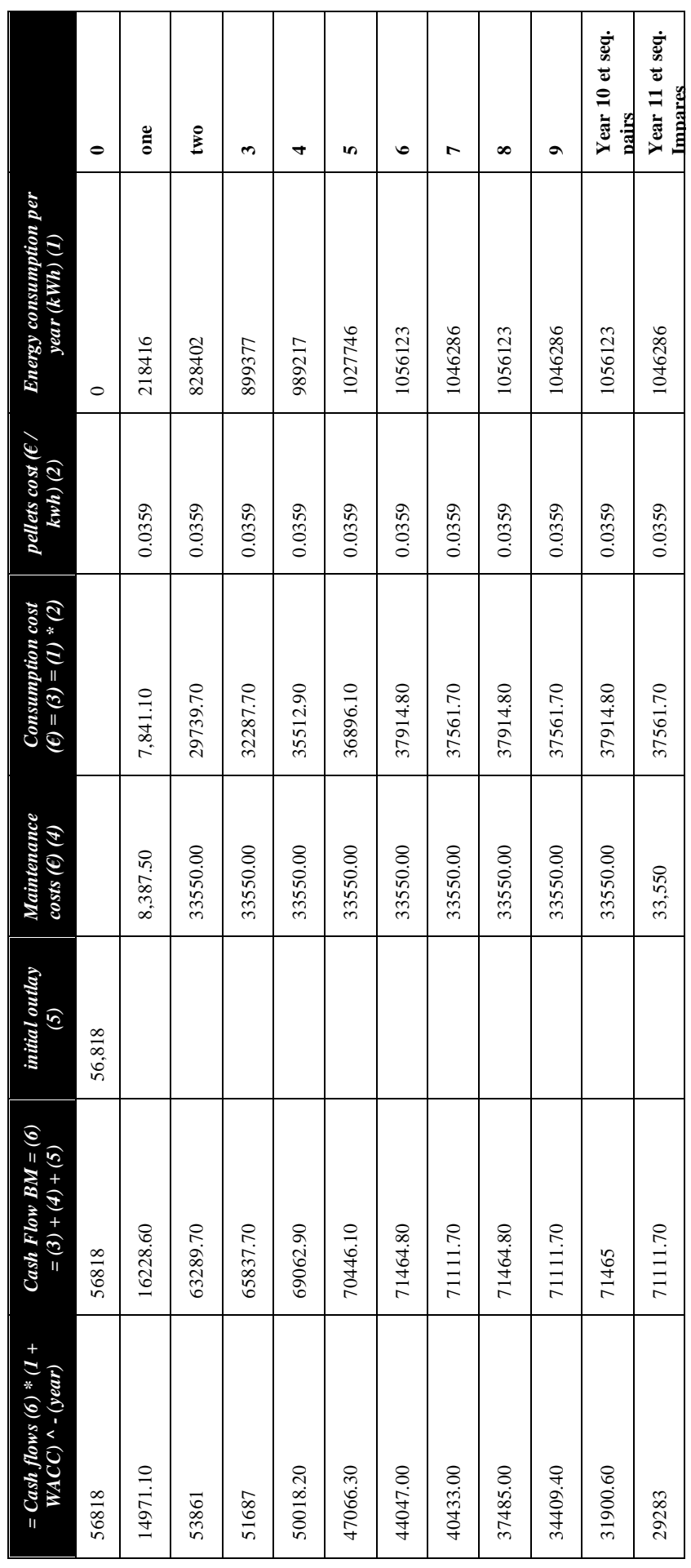

Table 10.2 Summary of total costs $(€)$ for installation of biomass breakdown and cash flows to calculate the NPV

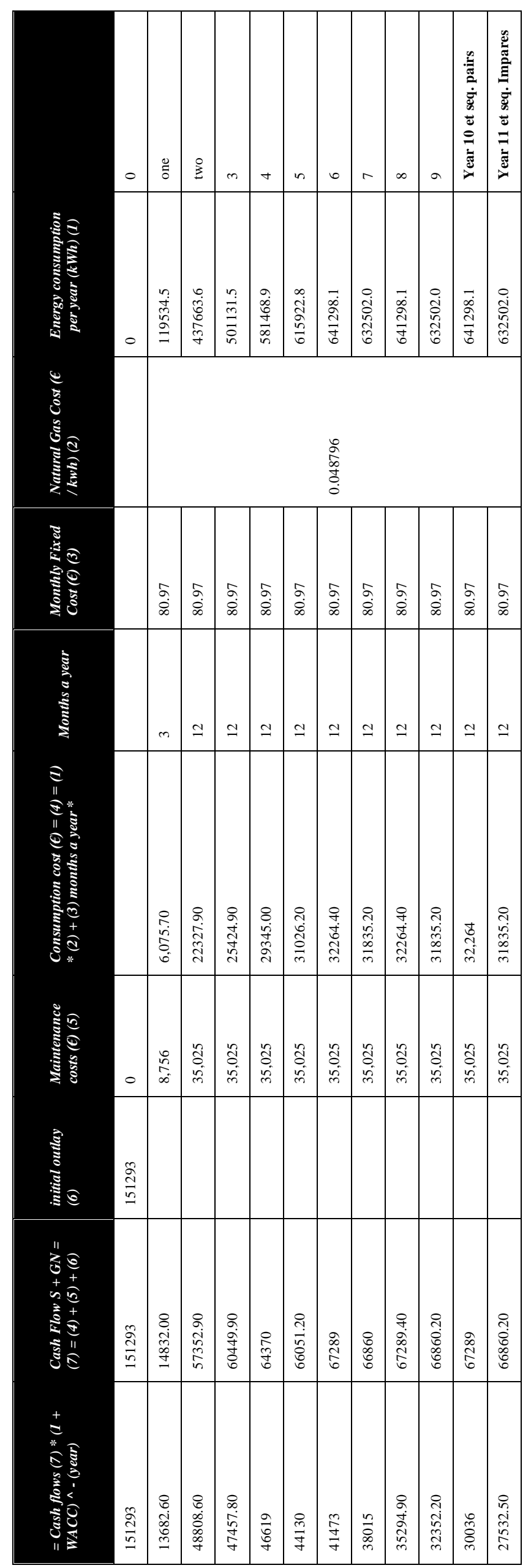

Table 10.3 Summary of total costs $(€)$ disaggregated Solar Installation with Natural Gas and cash flows to calculate the NPV

LONGARELA-ARES, Angeles. Financial viability and environmental aspects in the selection of energy sources for sanitary hot water (SHW) and heated swimming pools. ECORFAN Journal-Mexico. 2019 
December 2019 Vol.10 No.23 46-71

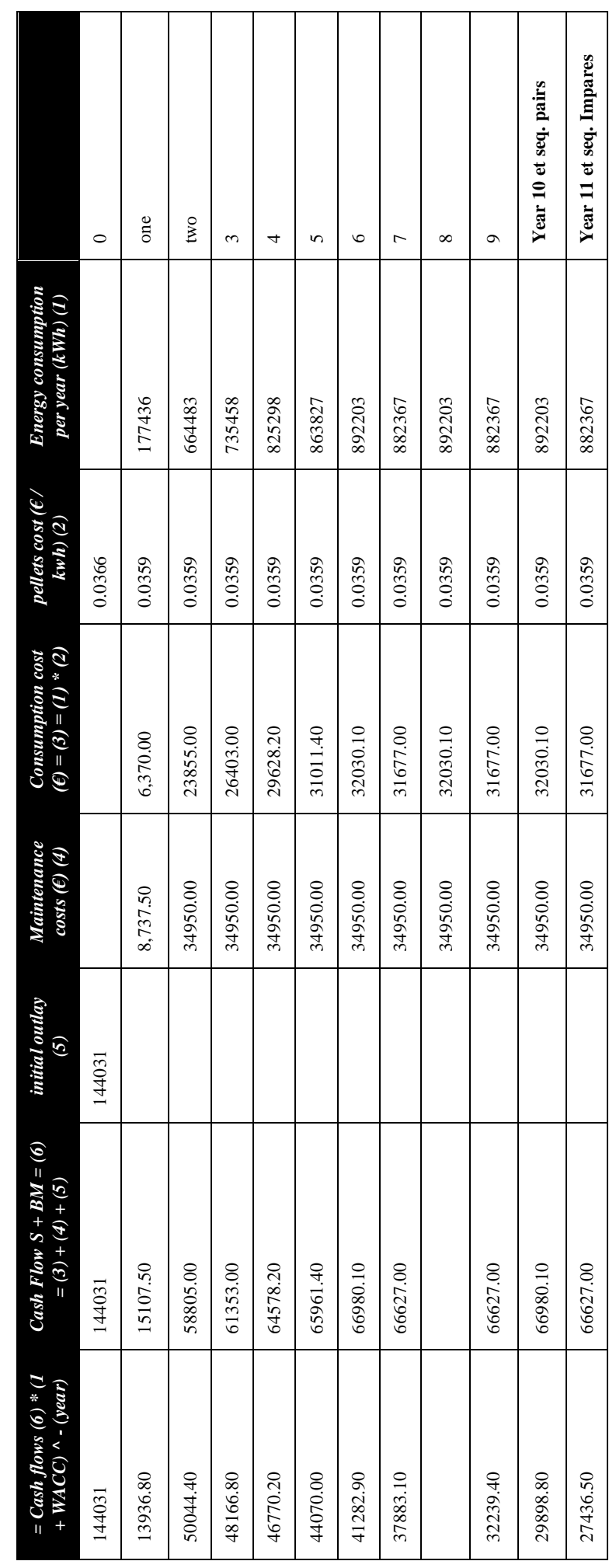

Table 10.4 Summary of total costs $(€)$ broken down for installation of Solar Biomass and cash flows to calculate the NPV

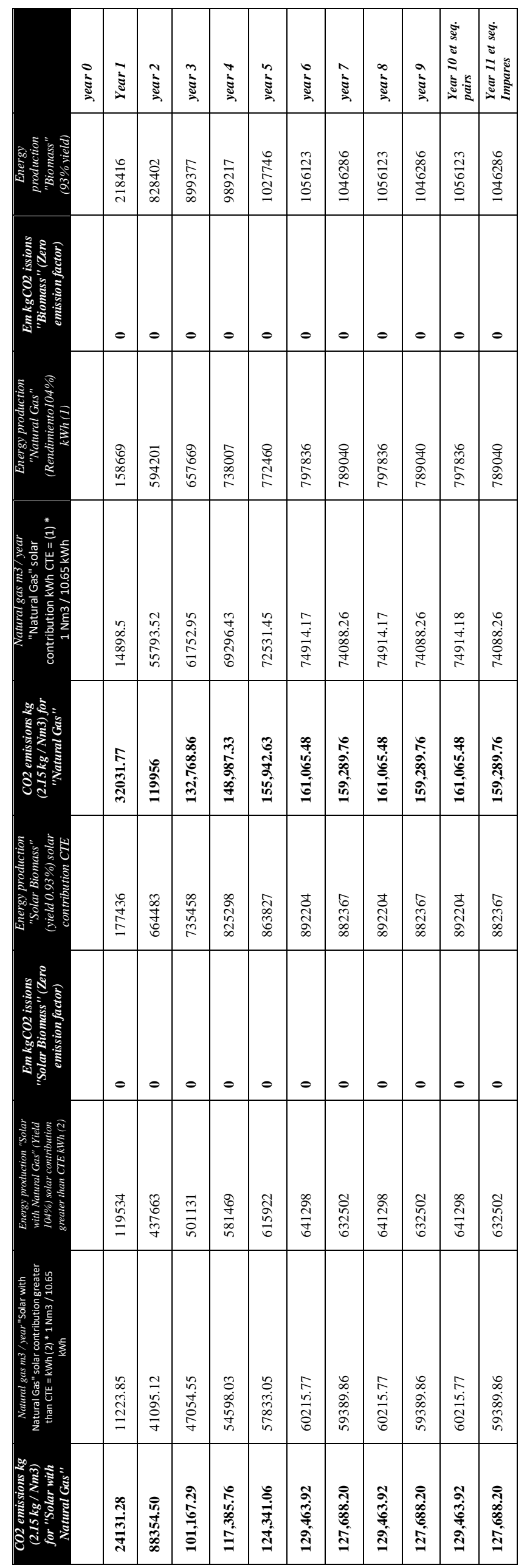

Table 12 Consumos energy $(\mathrm{kWh})$ estimated for each type of installation based on what is necessary to produce and $\mathrm{CO} 2$ emissions generated

LONGARELA-ARES, Angeles. Financial viability and environmental aspects in the selection of energy sources for sanitary hot water (SHW) and heated swimming pools. ECORFAN Journal-Mexico. 2019 
December 2019 Vol.10 No.23 46-71

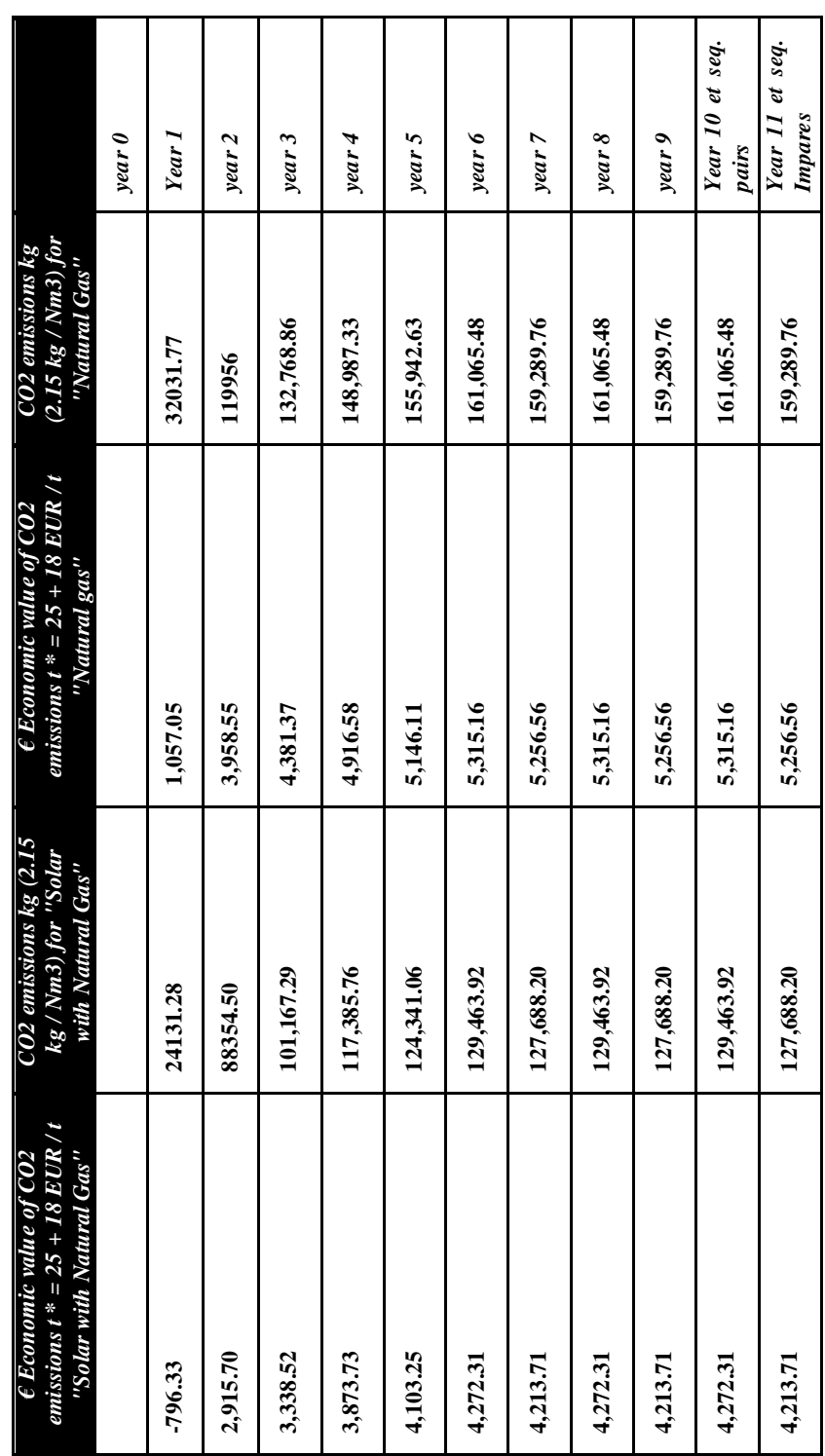

Table 13 Economic value $(€) \mathrm{CO} 2$ emissions at the consumption stage (external costs)

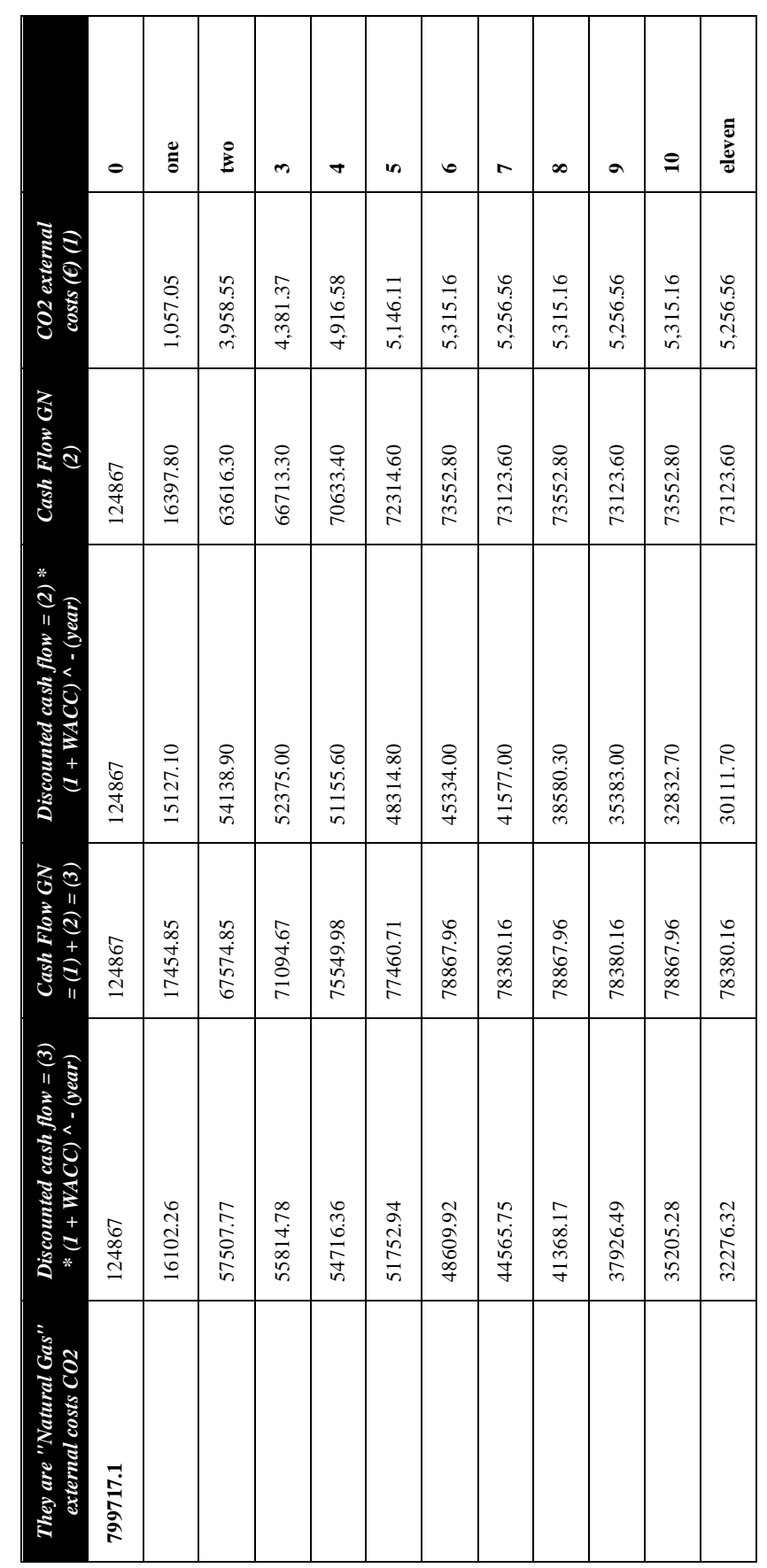

Table 14.1 Total cost $(€)$ for installation "Natural Gas" cash flows to calculate the NPV and NPV taking into account the external costs of $\mathrm{CO} 2$ emissions at the consumption stage 


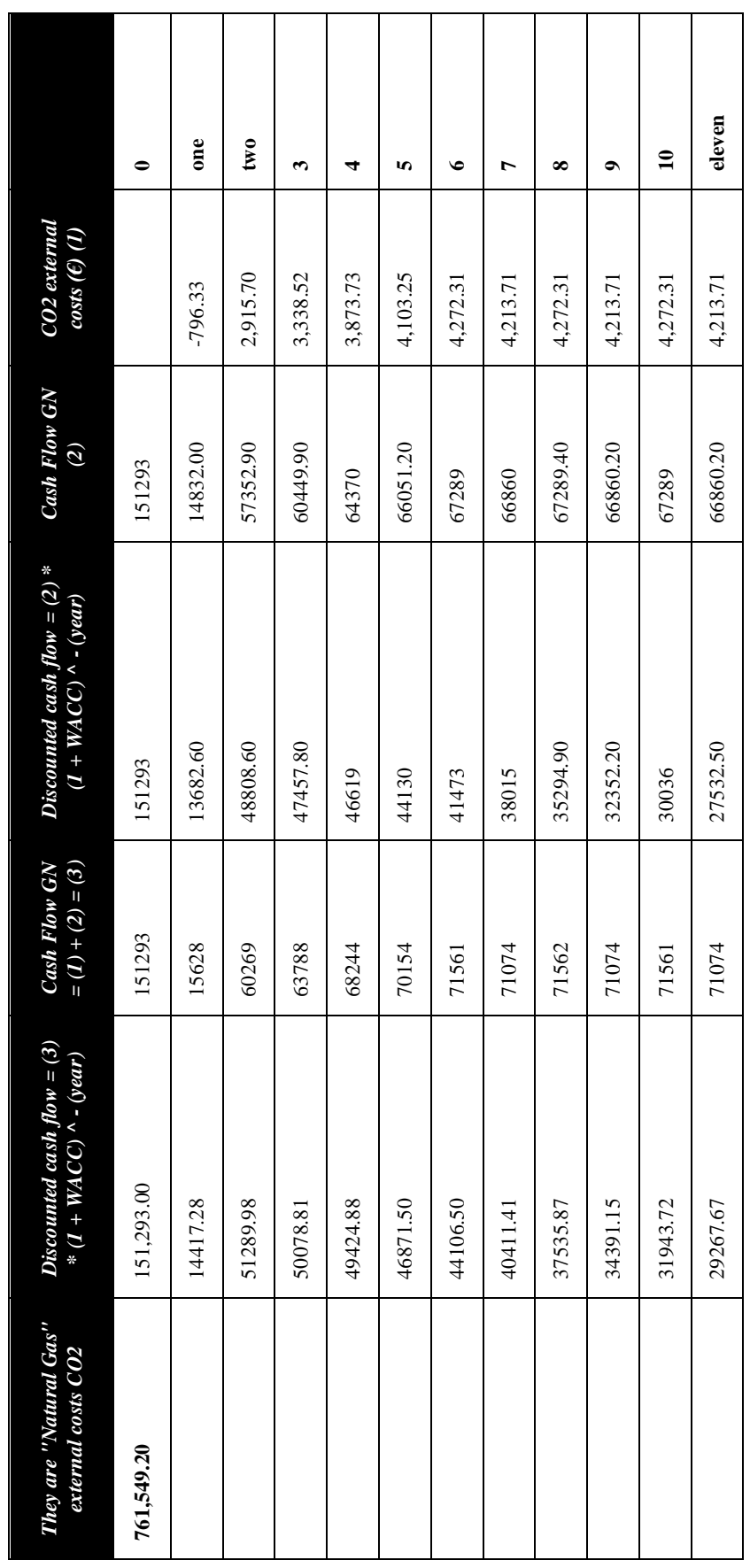

Table 14.2 Total cost $(€)$ for installation "Solar with Natural Gas" cash flows to calculate the NPV and NPV taking into account the external costs of $\mathrm{CO} 2$ emissions at the consumption stage 